\title{
GLOBALIZATION, INCREASING RETURNS IN COMPONENT PRODUCTION, AND THE PATTERN OF TRADE
}

\author{
Anu Kovaříková Arro
}
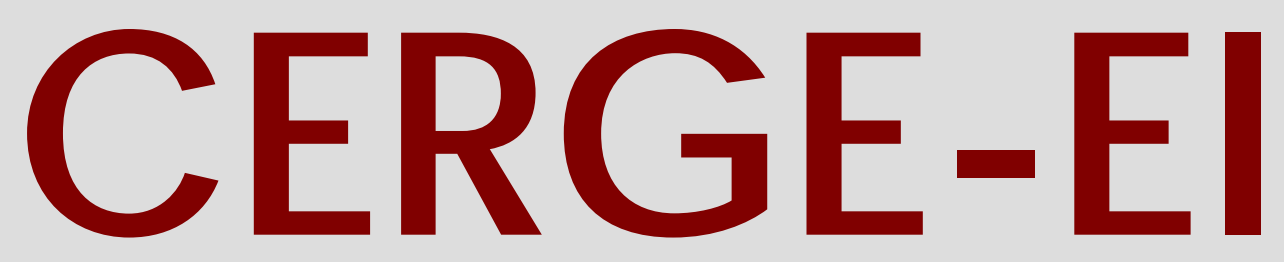

Charles University Centerfor Ec onomic Research and Graduate Educ ation Academy of Sciences of the Czech Republic Ec onomic Institute 


\title{
Working Paper Series 265 (ISSN 1211-3298)
}

\section{Globalization, Increasing Returns in Component Production, and the Pattern of Trade}

\author{
Anu Kovaříková Arro
}

CERGE-EI

Prague, June 2005 
ISBN 80-7343-057-6 (Univerzita Karlova v Praze, CERGE)

ISBN 80-7344-046-6 (Národohospodářský ústav AV ČR, Praha) 


\title{
GLOBALIZATION, INCREASING RETURNS IN COMPONENT Production, AND the PATtern OF TRADE
}

\author{
Anu Kovaříková Arro*
}

\begin{abstract}
This paper proposes that globalization, through the enlargement of the market, can influence both specialization and the equilibrium firm size. By re-introducing two factors of production into the muchutilized Dixit-Stiglitz-Ethier framework, I show that gains from specialization depend only on capital, while gains from increasing firm size face a trade-off between labor and capital as the size of the market expands. If the markup that the firms charge is instead endogenously determined, I demonstrate how firms can gain from both internal and external economies as globalization occurs if the number of firms stays under a specified threshold. The paper also shows that opening up to free trade in intermediate inputs and a final consumption good will have relative endowments determining the direction of trade across the stages of production. The model predicts that a relatively capital-abundant country will be the importer of the final good and the net exporter of intermediate components. Compared to autarky, trade will enhance specialization and firm size in the capital-abundant country and diminish both in the laborabundant country. Welfare can either increase or decrease as a result of trade.
\end{abstract}

\begin{abstract}
Abstrakt
Tento článek předkládá, že globalizace, jež zvyšuje objem trhu, je schopna ovlivnit jak specializaci tak rovnovážnou velikost firmy. Je ukázáno, že po znovuzavedení dvou výrobních faktorů do běžně použivaného Dixit-Stiglitz-Ethierova modelu, výnosy plynoucí ze specializace závisí pouze na kapitálu, zatímco zisky plynoucí ze zvyšující velikosti firmy závisí na kompromisu mezi pracovní silou a kapitálem. Je ukázáno jak firmy mohou benefikovat $z$ interních a externích ekonomik prí působení globalizace, jestliže přirážka, kterou firma účtuje, je stanovena endogenně; a jestliže počet firem zůstane pod specifikovanou hranicí. Tento článek také ukazuje, že po otevření se volnému obchodu $v$ meziproduktech a konečném spotřebním zboži, budou směr obchodu určovat relativní zdroje země v různých stádiích výroby. Model předpovídá, že relativně kapitálem hojná země bude dovozcem konečného produktu a čistým vývozcem meziproduktů. $V$ porovnání $s$ autarkií, obchod podporuje specializaci a velikost firmy v relativně kapitálem hojné zemi a zmenší obojí v zemi, která je relativně hojná pracovní silou. Následkem obchodu se bohatství země může zvýšit nebo snižit.
\end{abstract}

JEL Classification: F12, L11

Keywords: monopolistic competition, external and internal economies of scale, trade across the stages of production

\footnotetext{
" CERGE-El, a joint workplace of the Center for Economic Research and Graduate Education, Charles University, and the Economics Institute of the Academy of Sciences of the Czech Republic, Politických vězñu 7, 11121 Prague 1, Czech Republic. Tel: (+420 2) 2400 5187, fax: (+420 2) 2421 1374, e-mail: anu.kovarikova@cerge-ei.cz.

An early draft of this paper was written while I was visiting University College Dublin, whose hospitality is greatly acknowledged, on a Marie Curie Fellowship. I wish to thank participants at the UCD seminar, CERGE-EI Brown Bag seminar and the European Trade Study Group 2004 Annual Conference for feedback, and I am grateful to Andrew Austin, Frank Barry, Carsten Eckel, Randall Filer, Evžen Kočenda, James Markusen, Peter Neary, Gérard Roland and Krešimir Žigić for valuable comments and suggestions. I am responsible for any errors.
} 


\section{Introduction}

Globalization in the world economy has brought about significant changes in the structure and geographical location of the production of firms. Globalization, as Deardorff (2001) notes, has in the economic literature been variously represented by international trade, foreign direct investment, factor mobility, and fragmentation. While earlier research in international trade examined the options of firms to either export or invest into a local production unit in a foreign country, the emergence of the multinational enterprise has added many more sides to the story. In particular, a new organizational form of production has evolved according to which firms no longer engage in the whole sequence of activities necessary in getting a product to the consumer, but concentrate on their core competence and outsource the rest. This has resulted in a vertical disintegration of production processes, giving rise to horizontally specialized supply chains, such that production is fragmented to a number of specialized producers operating at separate stages of production.

Indeed, as Grossman and Helpman (2005) observe, "we live in an age of outsourcing" (p. 135). Firms outsource an expanding range of activities by delegating the production of intermediate inputs or offering after-sale service to outside contractors. While outsourcing can and does occur within borders, it is the international outsourcing to external suppliers and affiliates that has gained dominance and the attention of researchers in recent years. In this regard outsourcing is often viewed as trade in specialized intermediate inputs, including the intrafirm trade of multinational firms. For instance, Hanson et al. (2004) report that in 1999, 93\% of exports by U.S. parent firms abroad consisted of inputs for further processing to their affiliates located in low-wage countries. Egger and Egger (2001) analyze panel data on outward processing, production and trade for the European Union 15 countries and determine that frequent travel of intermediate goods across borders is particularly prevalent in import-competing, 
relatively unskilled-labor intensive industries. However, as Yi (2003) points out, outsourcing is also accounted for by vertical specialization, which is a related concept to trade in intermediate inputs, but not an identical one, as vertical specialization is also responsible for trade across the stages of production (import of intermediates and export of a final good). Hummels et al. (2001) undertake to determine the extent of vertical specialization in the world economy using inputoutput tables and report that the growth in exports that use imported goods as inputs has accounted for $21 \%$ of the OECD countries' exports in the 1990 s and that vertical specialization grew by almost 30\% between 1970 and 1990 . There exists a variety of theoretical models that account for fragmentation and its importance in the global economy, including Antras and Helpman (2004), Deardorff (2001), Feenstra and Hanson (1996, 1998), Grossman and Helpman (2002a, 2002b, 2005) and Venables (1999), among many others.

It is thus observed that the era of vertically integrated firms has been phasing out, whereas a different business strategy of horizontal specialization, where companies choose to focus on one or two segments of the value chain, is pursued. An appropriate example of such a strategy appear to be industries that require high fixed capital costs and comprise complex assembly, where a large number of parts must be specified, manufactured and brought together - such as the motor vehicle and electronics industries (Sturgeon, 2002). Sturgeon (2002) reveals that in electronics, firms as different as Hewlett Packard and Ericsson have sold off most of their worldwide manufacturing infrastructure to contract manufacturers, while in the auto industry, Ford and General Motors have retained vehicle design and final assembly and outsourced most of their component and module design and production. How outsourcing matters in the car industry in the United States is pictured by Grossman and Helpman (2005), who cite the WTO to describe the production of an "American" car:

Thirty percent of the car's value goes to Korea for assembly, 17.5 percent to Japan for components and advanced technology, 7.5 percent to Germany for design, 4 percent to Taiwan and Singapore for minor 
parts, 2.5 percent to the United Kingdom for advertising and marketing services, and 1.5 percent to Ireland and Barbados for data processing. This means that only 37 percent of production value... is generated in the United States. (p. 135)

However, on the other end of the spectrum from fragmentation lies the literature on how globalization induces an increase in the size of the firm, instead of enforcing downscaling and specialization. Rajan and Zingales (1998) reveal that much of economic growth takes place through the size of existing organizations, such that in their sample of 43 countries, two-thirds of economic growth over the 1980s can be assigned to the growth in the size of existing firms, while only the remaining one-third can be assigned to the creation of new firms. There is furthermore abundant evidence on how globalization has influenced large-scale horizontal mergers and acquisitions, both inside and across borders, increasing internalized transactions (Evenett, 2003). For example, UNCTAD reports that since 1994, mergers and acquisitions have grown six-fold to become the dominant form of foreign direct investment in the world. Also Sturgeon (2002) notes that the shift from vertical integration towards horizontal specialization has in some industries been followed by considerable horizontal consolidation inside a value chain segment.

The purpose of this paper is to build on the literature and evidence above to improve on several theoretical predictions on how globalization enforces specialization and firm size in monopolistically competitive industries. In particular, research on specialization models has to a large extent been based on Ethier's (1982) seminal work, whose key insight was that the DixitStiglitz (1977) model of preference for variety, when applied to production, constitutes the basis for a model of the division of labor (Francois and Nelson, 1998). Ethier (1982) developed a framework that explicitly showed how scale economies resulting from an increased division of labor, instead of increased firm size, depend (at an aggregate level) upon the size of the world market. In other words, production does not need to be geographically concentrated to allow reaping gains from specialization. However, since the solution to the Ethier (1982) model with 
one factor of production implies a firm size that is fixed, anything that enhances the size of the market would lead to increased specialization and no gains from increased firm size could arise. Eckel (2004) contrasts to this result: he disentangles the advantages of external economies (specialization) and internal economies (firm size), and by utilizing different cost functions, he is able to determine whether new firms enter, or existing firms grow, when globalization occurs.

In this paper I draw on the work by Rivera-Batiz and Rivera-Batiz (1991), who showed that firm size in the Ethier (1982) framework is not constant as two factors of production are incorporated into the model. By re-introducing two factors of production (labor and capital) into the Dixit-Stiglitz-Ethier setup, I am able to relate to the empirical evidence on why globalization in some cases seems to enhance specialization and in other cases enforces enlargement in firm size. I develop a three-sector model of final, intermediate and non-tradable goods that incorporates both internal and external economies, to show that the impact of an interaction between these economies of scale allows reaching a new understanding of the formation of the equilibrium horizontal industrial structure. The production of the final good in the model is composed of two separate production stages: input manufacturing and input processing. I follow Grossman and Helpman (2005) in assuming that the final good producers cannot manufacture intermediate inputs themselves or it is prohibitively costly for them to do so. Compared to Ethier (1982), this formulation also implies that the assembly of all intermediate components into the final manufacturing good is not costless, but requires labor input. In relation to the literature I hence put forward that outsourcing (initially at home in autarky and thereafter also abroad) has already taken place. I confirm that the number of firms active in the monopolistically competitive sector will be determined by capital endowment and labor will have no impact. The firm size on the other hand will face a trade-off between labor and capital, such that firm size can increase, decrease or stay constant when the market enlarges. Specifically, the addition of capital into the 
economy will always increase specialization and reduce the firm size, while the addition of labor can only enlarge firms.

The paper next relaxes the standard monopolistic competition assumption of exogenous markup to account for the price-index effect, hence the markup in the component producing sector will be endogenously determined. I show that the number of firms active in producing specialized components will have an impact on how capital augmentation in the economy will affect the equilibrium industrial structure. I prove that if the number of firms stays under a specified threshold, gains from both internal and external economies can be exploited from capital inflow, thereby leading to a simultaneous increase in specialization and firm size. Labor inflow continues to be able to only cause an increase in firm size. This result may help to explain why in Mexico's maquiladora sector there has been a consistent tendency towards larger companies and deepening specialization along a few lines of production (Gerber, 2000).

Another contribution of the paper relies on examining free trade in specialized intermediate inputs and a final manufacturing good as a source of an enlargement of the market to show how the pattern of trade across the stages of production evolves. Two countries that engage in trade in this model are identical in all other respects except their relative factor endowments, whereas the incentive for trade is triggered by a larger number of intermediate components becoming available. I determine that free trade across the stages of production will lead to factor price equalization and the endowment basis determination of the pattern of trade. Under costly assembly, a relatively capital-abundant country will become the importer of the final good and the net exporter of intermediate components. The model also predicts that as a result of trade, horizontal specialization and firm size in the component producing sector will increase in a relatively capital-abundant country and decrease in a relatively labor-abundant country. 
The results above are reflected by WTO International Trade Statistics (2004), which reports that in 2003, "a dramatic change in regional trade flows resulted from the new division of labor in Asia. Many producers in Japan and other high income economies in the region no longer export their finished goods to North America and Western Europe but ship high value-added components to China for assembly and send the end products from China through their affiliates to the Western markets" (p. 1). Hummels et al. (1998) affirm that the Japanese electronics industry has rapidly been outsourcing some stages of production, especially final assembly, to Southeast Asia and other developing countries, such that the export share of components in the whole electronics industry has reached nearly $80 \%$. $\mathrm{Ng}$ and Yeats (1999) similarly find that relatively low-wage East Asian countries have improved their comparative advantage in (laborintensive) assembly operations across 60 component product groups, whereas Japan, Singapore and Taiwan have increased their specialization in the production of components. Such specialization and trade pattern between countries with different capital-labor ratios is also verified by a recent study by Kandogan (2003), who empirically analyses trade between transition economies and developed countries to find that vertical intra-industry trade (defined as the simultaneous export and import of goods in the same industry, but at different stages of production) is positively affected by the economies of scale and comparative advantage.

Finally, the welfare impact of trade in this model depends on parameter values and the differences in relative factor endowments between the countries. The welfare of a relatively capital-abundant country is not much influenced by changes in factor abundance, while that of a relatively labor-abundant country is, since it experiences more significant adjustment in factor prices as a result of trade. Both countries are likely to gain from trade if they are very dissimilar in their capital-labor ratios, even so that the welfare gain of a labor-abundant country can exceed that of a capital-abundant country. 
The rest of the paper is structured as follows. Section 2 develops a three sector of production model and presents all assumptions. Section 3 solves for the general equilibrium outcome of the model with exogenous and endogenous markups. Section 4 allows free trade in specialized intermediate inputs and a final manufacturing good to study the pattern of trade and the resulting effect on specialization. This section also establishes the welfare implications of trade. Section 5 offers concluding remarks.

\section{The Model}

Consider an economy consisting of three sectors of production: a final manufacturing good sector $Q_{m}$, an intermediate good sector $I_{m}$ and a non-tradable good sector $Q_{s}$. The final good sector and the non-tradable good sector are perfectly competitive with constant returns to scale and have firms that are price takers at both output and input markets. The intermediate good sector on the other hand exhibits Ethier's (1982) formulation of economies of scale founded on the Dixit-Stiglitz love-of-variety approach.

Formally, the final manufacturing good sector's production function is given by

$$
Q_{m}=L_{m}^{\gamma} I_{m}^{1-\gamma}
$$

where $L_{m}$ is labor directly employed in producing the final good and $0<\gamma<1$ is the factor share of labor in final output. I assume here that the production of the final good is composed of two separate production stages: input manufacturing and input processing. This reasoning has been utilized in the recent empirical application by Hanson et al. (2004), as it allows visualizing that input manufacturing involves producing specialized components and may therefore be relatively capital intensive, while input processing in the view of assembly can be thought of as being relatively labor intensive. Previous literature has also termed the above relationship as being between an upstream industry (component producers) and a downstream industry (final 
good producers), allowing to study linkage effects. Compared to Ethier (1982), this formulation implies that the assembly of all intermediate components into the final manufacturing good is not costless, but requires labor input. Components here are assembled into the final good by many competitive firms.

The CES-type intermediate good sector's production function is expressed by

$$
I_{m}=n^{\frac{1}{\rho}-\frac{\sigma}{\sigma-1}}\left(\sum_{i=1}^{n} x_{i}^{\frac{\sigma-1}{\sigma}}\right)^{\frac{\sigma}{\sigma-1}}
$$

where $x_{i}$ is the output of an individual intermediate component, $I_{m}$ the total output of intermediates, $n$ is the number of suppliers of specialized components, $\sigma>1$ denotes the elasticity of substitution between the various components allowing for imperfect substitutability, and $0<\rho<1$ implies scale economies resulting from an increased division of labor, as addressed by Ethier (1982). Notice the different role parameters $\rho$ and $\sigma$ play in such a formulation, since $\rho$ measures the productivity enhancing effect of specialization explicitly and $\sigma$ the elasticity of demand and hence the market power of a typical firm (Neary, 2003b). Here lower values of $\sigma$ would indicate greater product differentiation within intermediate goods manufacturing as it is more difficult to substitute between the components.

Given the symmetry by which individual components enter the production function of the intermediate good and the same cost functions as will be discussed below, in the equilibrium the amount of output of each component producer will be the same or $x_{i}=x$. Then the intermediate good production function reduces to

$$
I_{m}=n^{\frac{1}{\rho}-1}(n x)=n^{\frac{1}{\rho}} x
$$

such that the aggregate output quantity of all produced components in the industry is $n x$. This production function displays constant returns to scale for a given number of produced 
components $n$, but an expansion of the intermediate good sector arising from an increased number of components (a rise in $n$ with constant $x$ ) exhibits increasing returns, as $I_{m}$ increases faster than $n x$ (Ethier, 1982). In such a production context $n$ can therefore be interpreted as a measure of the degree of specialization that depends on the size of the market for intermediate goods. Therefore, if the industry was perfectly specialized, $n x$ would be spread out over an infinite number of component producers, or $n \rightarrow \infty$ and $x \rightarrow 0$. I assume that the division of labor is limited by the extent of the market as otherwise the gains from specialization would lead to the production of an infinitesimal amount of an infinite number of separate components (Ethier, 1982). The division of labor has an effect in this model through $\rho$, as $n^{\frac{1}{\rho}-1}$ represents a shift parameter in the intermediates' production implying the existence of the endogenous external economies of scale to individual firms (Rivera-Batiz and Rivera-Batiz, 1991). Consequently, an increase in the number of manufactured components through increased specialization will yield higher marginal and average productivity in the intermediates' production, rising total factor productivity. Such external economies are treated as constant by each firm in the intermediate good industry as in the market equilibrium each firm maximizes its profit subject to the internal economies of scale and a zero profit constraint (Chipman, 1970).

The production of an individual component $x_{i}$ requires both capital and labor input in this monopolistically competitive industry. Following the standard Chamberlinian framework, and for simplicity, I let the technology used by all individual firms be identical. In particular, I assume that capital enters as a fixed input and labor as a variable input, such that the cost function of a component producing firm is

$$
c_{i}=r \theta+w \lambda x_{i}
$$


where $\theta>0$ denotes a fixed capital requirement, $\lambda x_{i}(\lambda>0)$ is the labor demanded by each component producer, $r$ is the interest rate and $w$ is the wage rate. Production with such input requirements represents increasing internal economies of scale as the average cost function derived from (4), $A C=\frac{r \theta}{x_{i}}+w \lambda$, is decreasing in an individual firm's size at all levels of output, although at a diminishing rate. Due to the presence of a fixed cost no two firms will produce the exact same component in the equilibrium as goods can be differentiated costlessly. Notice from (2) that components were assumed to contribute in the same way to the production, therefore perhaps raising questions about their actual differentiability. Analogous to Krugman (1981) this formulation can be satisfied as a restriction on the parameters of a more general model. $^{1}$

The production of the non-tradable good takes the form

$$
Q_{s}=A L_{s}^{\beta} K_{s}^{1-\beta}
$$

where $L_{s}$ is the amount of labor and $K_{s}$ the amount of capital employed in producing nontradables. $A=\frac{1}{\beta^{\beta}(1-\beta)^{1-\beta}}$ and $0<\beta<1$ is the factor share of labor in non-tradables' output.

On the demand side I assume that all individuals in the economy have the same CobbDouglas utility and due to identical and homothetic preferences the aggregate utility function takes the form $U=Q_{m}{ }^{\alpha} Q_{s}{ }^{1-\alpha}$, where $0<\alpha<1$. Maximizing this utility function subject to the budget constraint allows to derive aggregate demand for the manufacturing good $Q_{m}$ and the

\footnotetext{
1 Proof for the consumption case can be found in the appendix of Krugman (1981). As the assumptions on the parameters in the cost function and weights assigned in the production function are granted, one can justify the model by a choice of units. For this let components enter the production in (2) with different weights and adjust the labor requirement in the cost function accordingly, keeping fixed cost the same. Then one can make use of component 3 in units of 1 and component 15 in units of 10 , for example.
} 
non-tradable good $Q_{s}$. National income consists of wage and interest rate payments. Let $p_{m}$ denote the price of the manufacturing good and $p_{i}$ the price of an individual component; $P_{I}=n^{\left(\frac{\sigma}{\sigma-1}-\frac{1}{\rho}\right)}\left[\sum_{i=1}^{n} p_{i}^{1-\sigma}\right]^{\frac{1}{1-\sigma}}$ is then the composite price index for the intermediate good, which reduces in a symmetric equilibrium to $P_{I}=n^{1-\frac{1}{\rho}} p$. The non-tradable good is the numéraire.

The full employment of labor and capital in the economy imply that

$$
\lambda n x+L_{m}+L_{s}=\bar{L}
$$

and

$$
\theta n+K_{s}=\bar{K}
$$

where $\lambda n x$ is the amount of labor, $\theta n$ is the amount of capital demanded in the intermediate

good production, $\bar{L}$ denotes labor endowment and $\bar{K}$ capital endowment in the economy. Labor and capital are assumed to be perfectly mobile across the three production sectors.

This completes the setup of the model.

\section{General Equilibrium}

\subsection{Exogenous markup}

The producers of the non-tradable good maximize their profits in the perfectly competitive environment by choosing the optimal input mix of labor and capital, taking the prices of inputs and the output as given. The first order conditions from the profit maximization result in (as $\left.p_{s}=1\right)$ :

$$
\beta \frac{Q_{s}}{L_{s}}=w \text { and }(1-\beta) \frac{Q_{s}}{K_{s}}=r \Rightarrow \frac{1-\beta}{\beta} \frac{L_{s}}{K_{s}}=\frac{r}{w}
$$


Competition in the non-tradable good industry brings about marginal cost (equals average cost) pricing, and since the unit cost is $C_{s}=\frac{1}{A}\left(\frac{w}{\beta}\right)^{\beta}\left(\frac{r}{1-\beta}\right)^{1-\beta}$,

$w^{\beta} r^{1-\beta}=1 \Rightarrow w=r^{\frac{\beta-1}{\beta}}$.

Firms that produce various components take the composite price index for the intermediate good as well as the national income as given and each firm maximizes its profits by choosing the price of a component. As there is no asymmetry in the substitutability of components, the choice of the degree of differentiation relative to other products is not introduced at entry and firms simply decide whether to enter or not. Profit maximization equates marginal revenue to marginal cost. Hence I assume in the standard Chamberlinian fashion that each producer conjectures that the other firms in the sector will not change their output in response to that firm's price change and that there is a large enough number of firms producing components unable to influence the total output of the intermediate good sector (Rivera-Batiz and RiveraBatiz, 1991). Then the demand for each component by manufacturing producers faces a constant price elasticity of $\sigma$ that is exogenously given by the elasticity of substitution. This price elasticity in turn determines the markup that the firms charge. Hence the price of each component is a constant markup over the marginal cost

$$
p_{i}\left(1-\frac{1}{\sigma}\right)=w \lambda \Rightarrow p_{i}=\frac{\sigma}{\sigma-1} w \lambda
$$

It can immediately be seen that with identical technology all firms charge the same price for each component or $p_{i}=p$. Equation (10) then states that the markup is inversely related to the elasticity of substitution between the various components.

Free entry on the other hand does not allow the firms to charge a price higher than the average cost, driving profits to zero and making it unprofitable to share the demand for any given 
component with any other firm. Chamberlinian properties of this equilibrium require the tangency condition between demand and the average cost curve to hold, as marginal revenue equals marginal cost and price equals the average cost simultaneously (Neary, 2003b). Free entry thus results in

$$
p=\frac{r \theta}{x_{i}}+w \lambda \Rightarrow x_{i}=\frac{r \theta}{w \lambda}(\sigma-1)
$$

Since firms have the same technology and face the same elasticity of substitution between components, each firm operating in this monopolistically competitive sector produces the same level of output in the equilibrium or $x_{i}=x$.

With the same prices and output levels for the components in intermediate good production, total output $I_{m}=n^{\frac{1}{\rho}-\frac{\sigma}{\sigma-1}}\left(\sum_{i=1}^{n} X_{i}^{\frac{\sigma-1}{\sigma}}\right)^{\frac{\sigma}{\sigma-1}}$ reduces to $I_{m}=n^{\frac{1}{\rho}} X$ and the composite price index $P_{I}=n^{\left(\frac{\sigma}{\sigma-1}-\frac{1}{\rho}\right)}\left[\sum_{i=1}^{n} p_{i}^{1-\sigma}\right]^{\frac{1}{1-\sigma}}$ reduces to $P_{I}=n^{1-\frac{1}{\rho}} p$.

The above implies that in a symmetric equilibrium

$$
P_{I} I_{m}=n p x
$$

or the total revenue in the intermediate good sector equals the total revenue from manufacturing all the components.

The producers of the final manufacturing good maximize their profits in the perfectly competitive environment by choosing the optimal input mix of labor and intermediate goods, taking the prices of inputs and the output as given. The first order conditions from the profit maximization result in

$$
p_{m} \gamma \frac{Q_{m}}{L_{m}}=w \text { and } p_{m}(1-\gamma) \frac{Q_{m}}{I_{m}}=P_{I}
$$


Consumers in the economy maximize their utility $U=Q_{m}{ }^{\alpha} Q_{s}{ }^{1-\alpha}$ subject to the budget constraint $p_{m} Q_{m}+Q_{s}=I$, where $I=w \bar{L}+r \bar{K}$ stands for national income. Then a share $\alpha$ of the income will be spent on final manufacturing goods and a share $(1-\alpha)$ on nontradables. Formally, $p_{m} Q_{m}=\alpha I$ and $Q_{s}=(1-\alpha) I$.

I solve for the equilibrium in this autarkic economy by utilizing equation (12) and noticing that the zero profit condition expressed by equation (11) equates total revenue with total cost in each component-producing firm. The first order conditions of the final good producers' profit maximization in (13) imply that the total spending of the manufacturing good sector on intermediate inputs equals an exogenous share of its revenue. Since the share of income spent on manufacturing goods must equal the sales in that industry,

$$
n p x=n c=n(r \theta+w \lambda x)=P_{I} I_{m}=(1-\gamma) \alpha I .
$$

Equation (14) allows to express $n$ as the function of exogenous parameters, capital and labor endowments in the economy, and the wage rate. In particular,

$$
n=\frac{(1-\gamma) \alpha\left(\bar{K}+w^{\frac{1}{1-\beta}} \bar{L}\right)}{\sigma \theta}
$$

The first order conditions from profit maximization in non-tradable production in (8) imply that $L_{s}=\beta(1-\alpha)\left(\bar{L}+w^{\frac{1}{\beta-1}} \bar{K}\right)$ and $L_{s}=\left(\frac{\beta}{1-\beta}\right) K_{s} w^{\frac{1}{\beta-1}}$. The full employment of capital in the economy in (7) on the other hand means that $K_{s}=\bar{K}-n \theta$. Then

$$
\left(\frac{\beta}{1-\beta}\right)(\bar{K}-n \theta) w^{\frac{1}{\beta-1}}=\beta(1-\alpha)\left(\bar{L}+w^{\frac{1}{\beta-1}} \bar{K}\right)
$$

and after substituting for $n$ from equation (15) the solution for the wage rate becomes

$$
w=\left(\frac{\bar{K}(\sigma-(1-\gamma) \alpha-(1-\beta) \sigma(1-\alpha))}{\bar{L}((1-\beta) \sigma(1-\alpha)+(1-\gamma) \alpha)}\right)^{1-\beta}
$$


Equation (17) shows that the wage rate in the economy is influenced by capital and labor endowments, parameters $\alpha, \beta, \gamma$ and the elasticity of substitution $\sigma$. An increase in the capital stock (labor force) ceteris paribus would lead to an increase (decrease) in the wage rate. This result contrasts to Krugman (1980), in that it is the country that is relatively more capitalabundant that has a higher wage.

Next I solve for the interest rate by using equation (9), such that

$$
r=\left(\frac{\bar{L}((1-\beta) \sigma(1-\alpha)+(1-\gamma) \alpha)}{\bar{K}(\sigma-(1-\gamma) \alpha-(1-\beta) \sigma(1-\alpha))}\right)^{\beta}
$$

which depends on the same variables as the wage rate. Here an increase in the capital stock (labor force) ceteris paribus would lead to a decrease (increase) in the rental rate, identifying the factor price effect of the change in endowment. Now the country that is relatively more capitalabundant has a lower interest rate.

Equations (15) and (17) subsequently allow deriving the solution for $n$ in the economy that has a monopolistically competitive sector with exogenous markup. Due to the presence of a fixed cost, there can only be a finite number of firms operating in the equilibrium. Specifically (ignoring the integer constraint),

$$
n=\frac{(1-\gamma) \alpha}{\theta} \frac{1}{(1-\beta) \sigma(1-\alpha)+(1-\gamma) \alpha} \bar{K}
$$

Notice here that the number of firms in the sector producing components (the equilibrium degree of specialization) depends only on the stock of capital in the economy and parameter values, being independent of the labor endowment. This parallels the solution reached by RiveraBatiz and Rivera-Batiz (1991) for a two-sector economy that also utilizes two factors of production in the monopolistically competitive sector. On the other hand, such solution diverges from the more common result that is derived from using only one factor of production in the monopolistically competitive sector, labor. In given model, labor endowment in the economy (the 
size of $\bar{L}$ ) has absolutely no impact on the number of firms in the equilibrium. Moreover, the dependency of $n$ solely on the capital endowment does not result from the particular form of the final good production function presented in (2). Rivera-Batiz and Rivera-Batiz (1991) show, in a model where the final good is a Cobb-Douglas composite of labor, capital and intermediate goods, that the exact same relationship evolves.

The solution for the price and output in the component producing sector can be derived from (10) and (11) and results in

$$
p=\frac{\sigma}{\sigma-1} \lambda\left(\frac{\bar{K}(\sigma-(1-\gamma) \alpha-(1-\beta) \sigma(1-\alpha))}{\bar{L}((1-\beta) \sigma(1-\alpha)+(1-\gamma) \alpha)}\right)^{1-\beta}
$$

and

$$
x=\frac{\theta}{\lambda}(\sigma-1)\left(\frac{\bar{L}((1-\beta) \sigma(1-\alpha)+(1-\gamma) \alpha)}{\bar{K}(\sigma-(1-\gamma) \alpha-(1-\beta) \sigma(1-\alpha))}\right)
$$

Equation (21) implies that the output level of a component producer or the size of a firm is not fixed as in the Ethier-type models with one factor of production, but varies depending on the labor and capital endowment in the economy. An increase in the capital stock (labor force) ceteris paribus would lead to a decrease (increase) in the output of each component. The aggregate output quantity of all produced components in the industry $n x$ is however independent of the capital stock $\bar{K}$ and directly related to the labor force $\bar{L}$. The reason is that as the size of the market expands, an increasing labor force would lead to a decrease in the wage-rental ratio and thereby to an increase in the ratio of fixed to variable costs in the component producing firms. There would also be an increased demand for final manufactures and therefore intermediates. Then an expansion in the intermediate production would force each component producer to increase the quantity supplied, as specialization is kept unaffected and total quantity supplied expands. 
Capital used in the non-tradable sector in this economy follows from the full-employment condition expressed in (7). Labor employed in the manufacturing final good sector can be derived from the first order conditions of the manufacturing production in (13). In particular,

$$
L_{m}=n x \lambda\left(\frac{\gamma}{1-\gamma}\right)\left(\frac{\sigma}{\sigma-1}\right)
$$

and since the amount of labor employed in the intermediate good sector $L_{I}=n x \lambda$, it follows that the allocation of labor between manufacturing and the intermediate's production is solely determined by the parameters of the model. Labor used in the non-tradable sector can then be found from the full-employment condition in (6).

This completes the autarkic equilibrium of this model, as all endogenous variables ( $\left.n, p, x, r, w, p_{m}, P_{I}, I_{m}, Q_{m}, Q_{s}, L_{I}, L_{m}, L_{s}, K_{s}, U, I\right)$ can be solved by expressing them through exogenous variables (capital and labor endowment) and the parameters of the model.

To determine how globalization can affect different types of economies of scale in this model, I utilize the framework developed by Eckel (2004). As I already addressed in the setup, there are external economies of scale present in the intermediate good sector as long as $0<\rho<1$, reflecting gains from an increased division of labor and determining the level of specialization. Since in a symmetric equilibrium intermediate goods are produced according to $I_{m}=n^{\frac{1}{\rho}-1}(n x)=n^{\frac{1}{\rho}} X$, I define an index $\mu(n)=\frac{I_{m}}{n x}$ to capture gains from horizontal specialization explicitly. In the model with exogenous markup, gains from specialization are then determined from (19) and equal

$$
\mu(n)=n^{\frac{1}{\rho}-1}=\left(\frac{(1-\gamma) \alpha}{\theta} \frac{1}{(1-\beta) \sigma(1-\alpha)+(1-\gamma) \alpha} \bar{K}\right)^{\frac{1}{\rho}-1}
$$

Internal economies of scale are reflected by decreasing average costs in the production of components. Following Eckel (2004), I define the inverse of average costs as the measure of 
internal economies, so that this measure rises when the economies of scale increase. The presence of internal economies exhibits possible gains from increased firm size. Formally,

$$
\begin{gathered}
v\left(x_{i}\right)=\left(\frac{x_{i}}{c_{i}\left(x_{i}, r, w\right)}\right)=\left(\frac{1}{p_{i}}\right), \text { such that from }(20), \\
v(x)=\frac{\sigma-1}{\sigma} \frac{1}{\lambda}\left(\frac{\bar{L}((1-\beta) \sigma(1-\alpha)+(1-\gamma) \alpha)}{\bar{K}(\sigma-(1-\gamma) \alpha-(1-\beta) \sigma(1-\alpha))}\right)^{1-\beta} .
\end{gathered}
$$

Equation (23) discloses that the external economies of scale in the Dixit-Stiglitz-Ethier model with exogenous markup are affected by capital endowment only and that the size of the labor force $(\bar{L})$ has no impact on it (i.e. $\frac{\partial \mu}{\partial \bar{K}}>0$ and $\frac{\partial \mu}{\partial \bar{L}}=0$ ). As the stock of capital is augmented, ceteris paribus, the ratio of fixed to variable costs declines, inducing entry and enhancing specialization.

Equation (24) on the other hand shows that the adjustment in both capital and labor endowments has an impact on internal economies, and that they have a divergent effect on the final outcome. Specifically, it clearly follows from (24) that $\frac{\partial v}{\partial \bar{K}}<0$ and $\frac{\partial v}{\partial \bar{L}}>0$. As the size of the capital stock increases, the firms are scaled back, ceteris paribus, and as the size of available labor increases, ceteris paribus, a larger firm size would be encouraged by increased demand and by raising the ratio of fixed to variable costs. In this model, these effects offset each other if the endowments of the capital stock and labor force turn out to be equal and if they both grow at the same pace. This special outcome compares to the one factor of production Ethiertype models, in which the internal economies of scale are constant (as firm size is constant), such that an increase in the size of the market through globalization always enhances specialization and has no effect on firm size. The enhancement in specialization occurs through an increase in population in those models (and population reflects market size), not through an 
increase in capital stock as here. In given model an increase in labor endowment would not encourage the entry of new firms, but would result in gains from internal economies by expanding the existing ones.

Hence the inclusion of capital into the Dixit-Stiglitz-Ethier model makes an important adjustment: specialization depends only on the size of capital stock and internal economies of scale face a trade-off, except in a special case as explained above, as the market enlarges due to globalization. Notice that in this framework I let the size of the market be determined by total income as there are two factors of production. Then internal economies do not stay constant as long as globalization can augment the amount of existing capital (foreign direct investment) or increase the size of population (immigration) disproportionately. While an increase in population would enhance firm size, a possible simultaneous increase in capital stock would work against it, instead encouraging the entry of new firms.

I consequently assume that as globalization occurs, the market can be enlarged on the account of both capital and labor inflow. ${ }^{2}$ Proposition 1 summarizes the above discussion.

Proposition 1 If the component producing firms' markup is exogenous and two factors of production are employed, globalization would always increase specialization and could either increase, decrease or not affect the equilibrium firm size, depending on how much capital augmentation is able to offset that of labor as the market enlarges. The enlargement motive of firms is always supported if globalization expands the market through a significant population increase.

\footnotetext{
2 After substituting from (17) and (18), $I=w \bar{L}+r \bar{K}=\bar{K}^{1-\beta} \bar{L}^{\beta}\left(\frac{(1-\beta) \sigma(1-\alpha)+(1-\gamma) \alpha}{\sigma-(1-\gamma) \alpha-(1-\beta) \sigma(1-\alpha)}\right)^{\beta}$. $\cdot\left(\frac{\sigma}{(1-\beta) \sigma(1-\alpha)+(1-\gamma) \alpha}\right)$, such that total income will always increase with either capital or labor inflow.
} 


\subsection{Endogenous markup}

Models of monopolistic competition in which individual producers' markups do not depend on the number of producers abstract from interdependence among firms, since the number of firms in operation is assumed to be large as an approximation and hence a firm takes the composite price index for the intermediate good as well as the national income as given. Competition in prices implied earlier that producers set their marginal revenue equal to marginal cost, allowing to express (10) in the Chamberlinian fashion where the price elasticity of demand is a constant.

In this section I am interested in endogenizing the markup (through endogenizing the price elasticity of demand) that component producing firms charge, so that I would not completely eliminate expansion effects that can have an impact on the equilibrium horizontal industrial structure. I proceed along the lines of Eckel (2004), whose Ethier-type model with one factor of production permits the firm size to vary by labor endowment once the expansion effects are taken into account. Analogously to Eckel (2004), I wish to pursue the inclusion of expansion effects to see how globalization changes the prediction of industry structure, albeit constant firm size is not an issue here.

The demand for each component in a more general format can be derived from a cost function, corresponding to (2) and making use of Shepard's lemma. Then $C_{I}=\left(\sum_{i=1}^{n} p_{i}^{1-\sigma}\right)^{\frac{1}{1-\sigma}} n^{\frac{\sigma}{\sigma-1}-\frac{1}{\rho}} I_{m} \quad$ is the respective cost function and $x_{j}=n^{\left(\frac{\sigma}{\sigma-1}-\frac{1}{\rho}\right)(1-\sigma)}\left(\frac{P_{I}}{p_{j}}\right)^{\sigma} I_{m}=n^{\left(\frac{\sigma}{\sigma-1}-\frac{1}{\rho}\right)(1-\sigma)}\left(\frac{P_{I}}{p_{j}}\right)^{\sigma} \frac{(1-\gamma) \alpha}{P_{I}} I$ the derived demand for a

component $j$. The price elasticity of this demand can be shown to equal 


$$
\frac{\partial x_{j}}{\partial p_{j}} \frac{p_{j}}{x_{j}}=-\sigma+\left(\sigma+\frac{\partial(1-\gamma) \alpha}{\partial P_{I}} \frac{P_{I}}{(1-\gamma) \alpha}-1\right) \frac{\partial P_{I}}{\partial p_{j}} \frac{p_{j}}{P_{I}}+\frac{\partial I}{\partial p_{j}} \frac{p_{j}}{I}
$$

In addition to the substitution effect as expressed by the first term of (25), price elasticity of demand can be influenced by two additional effects, the impact of pricing behavior on the industry-wide price index (the price-index effect) and national income (the "Ford effect"). The importance of those effects depends on whether a single firm in the intermediate good industry is large enough to manipulate price index and income. In the Chamberlinian tradition of atomistic firms with no perceived interdependence, a firm is too small to have any influence, eliminating price-index and Ford effects from consideration.

I next relax this Chamberlinian assumption by assuming that a firm in the intermediate good industry is large enough to be able to influence the industry level price index, but is small enough not to have any significant impact on national income (d'Aspremont et al., 1996, Neary, 2003a, Yang and Heijdra, 1993). Then the Ford effect continues not to apply $\left(\frac{\partial I}{\partial p_{j}} \frac{p_{j}}{I}=0\right)$. I still assume that firms do not engage in any type of strategic behavior, such that expenditures on fixed and variable costs are incurred simultaneously. If each component producing firm takes the pricing behavior of all competitors as given, then $\frac{\partial P_{I}}{\partial p_{j}}=n^{\frac{\sigma}{\sigma-1}-\frac{1}{\rho}}\left(\sum_{i=1}^{n} p_{i}{ }^{1-\sigma}\right)^{\frac{\sigma}{1-\sigma}} p_{j}{ }^{-\sigma}$ and therefore $\frac{\partial P_{I}}{\partial p_{j}} \frac{p_{j}}{P_{I}}=\frac{p_{j}^{1-\sigma}}{\sum_{i=1}^{n} p_{i}^{1-\sigma}}$. In addition, since the Cobb-Douglas type of utility function implies that the income share spent on intermediate goods is exogenous, $\frac{\partial(1-\gamma) \alpha}{\partial P_{I}}=0$. Finally then, the price elasticity of demand in (25) reduces to

$$
\frac{\partial x_{j}}{\partial p_{j}} \frac{p_{j}}{x_{j}}=-\sigma+\frac{1}{n}(\sigma-1)
$$


in a symmetric equilibrium, where the technology of all firms is identical. ${ }^{3}$ Notice the difference from the constant elasticity of demand specified earlier, as now the price elasticity of demand for each component depends on how many components will be produced in total. Naturally then, the monopoly power of each firm increases if there are less than a large number of firms operating, making the demand less elastic if there is less specialization and vice versa. It is straightforward to show that the price of each component is no longer a constant markup over the marginal cost, but equals

$$
p=\left(\frac{1}{\sigma-1}\left(\sigma+\frac{1}{n-1}\right)\right) w \lambda
$$

implying that the price of a component is lower in the equilibrium with more specialization.

The output of each component, on the other hand, unlike (11), is now expressed by

$$
p=\frac{r \theta}{x}+w \lambda \Rightarrow x=\frac{r \theta}{w \lambda}(\sigma-1)\left(\frac{n-1}{n}\right)
$$

disclosing how the quantity produced by a single component manufacturer is made dependent on the number of active firms in the intermediate good industry given free entry.

I again solve for the equilibrium in this autarkic economy by utilizing equation (12) and the first order conditions of manufacturing producers' profit maximization in (13). The zero profit condition expressed in this endogenous markup model by equation (28) equates total revenue with total cost in each component producing firm. As the share of income spent on manufacturing goods must equal the sales in that industry, (14) can be expressed as before, which after some manipulation yields a new expression for the number of firms

\footnotetext{
3 Also see Yang and Heijdra (1993) for this result. There, $\frac{\partial x_{j}}{\partial p_{j}} \frac{p_{j}}{x_{j}}=-\sigma+\frac{1}{n}(\sigma-1)+\frac{\xi\left(P_{I}\right)}{n}$, where $\xi\left(P_{I}\right)=\frac{\partial s}{\partial P_{I}} \frac{P_{I}}{s}$ is the elasticity of the share function. In the model above, $s\left(P_{I}\right)=(1-\gamma) \alpha$, so $\xi\left(P_{I}\right)=0$.
} 


$$
n=\frac{(1-\gamma) \alpha\left(\bar{K}+w^{\frac{1}{1-\beta}} \bar{L}\right)+\theta(\sigma-1)}{\sigma \theta}
$$

Compared to the exogenous markup case as expressed by (15), there is an additional term present in (29), which will affect the equilibrium outcome, as will be shown below. Utilizing (16) and substituting for $n$ allows to solve for the wage rate as follows:

$$
w=\left(\frac{\bar{K}(\sigma-(1-\gamma) \alpha-(1-\beta) \sigma(1-\alpha))-\theta(\sigma-1)}{\bar{L}((1-\beta) \sigma(1-\alpha)+(1-\gamma) \alpha)}\right)^{1-\beta}
$$

Equation (30) reveals that the wage rate in the economy is lower when the markup of the component producers is endogenously determined. In particular, the additional term as expressed by $\theta(\sigma-1)$ has a negative impact on the equilibrium wage level, making labor cheaper. A relatively more capital-abundant country continues to have a higher wage, in addition, compared to the exogenous markup case, the difference in wages between countries increases for the same relative factor endowments. Even though the wage rate decreases in both countries compared to the solution under exogenous markup, it decreases proportionally more in a relatively labor-abundant country.

The expression for the interest rate follows directly from (9), which this time leads to

$$
r=\left(\frac{\bar{L}((1-\beta) \sigma(1-\alpha)+(1-\gamma) \alpha)}{\bar{K}(\sigma-(1-\gamma) \alpha-(1-\beta) \sigma(1-\alpha))-\theta(\sigma-1)}\right)^{\beta}
$$

and demonstrates that under endogenous markup capital is made more expensive. Similar to the wage rates, the disparity in interest rates increases between countries that differ in their relative factor endowments. Capital price will be higher in both countries compared to the exogenous markup case, while the increase in the interest rate is proportionally more pronounced in a laborabundant country. Compared to wages the interest rates diverge even more in this setup. 
Utilizing equations (29) and (30), the number of firms operating in the equilibrium with endogenous markup (ignoring the integer constraint) is expressed by

$$
n=\frac{(\sigma-1)(1-\beta)(1-\alpha)}{(1-\beta) \sigma(1-\alpha)+(1-\gamma) \alpha}+\frac{(1-\gamma) \alpha}{\theta} \frac{1}{(1-\beta) \sigma(1-\alpha)+(1-\gamma) \alpha} \bar{K}
$$

where the first term of (32) characterizes an increase in specialization brought about by an endogenized markup at a given absolute capital endowment. The number of component suppliers in the economy still depends only on the existing capital stock and parameters of the model, while labor endowment has no effect on this outcome.

Finally, equations (27) and (28) allow to solve for the price and output in the component producing sector under endogenous markup, resulting in

$$
\begin{aligned}
& p=\lambda \frac{\left(\frac{\sigma}{\sigma-1}\right) \bar{K}-\theta}{\bar{K}-\theta\left(\frac{(1-\beta)(1-\alpha)}{(1-\gamma) \alpha}+1\right)} \cdot \\
& \cdot\left(\frac{\bar{K}(\sigma-(1-\gamma) \alpha-(1-\beta) \sigma(1-\alpha))-\theta(\sigma-1)}{\bar{L}((1-\beta) \sigma(1-\alpha)+(1-\gamma) \alpha)}\right)^{1-\beta}
\end{aligned}
$$

and

$$
\begin{aligned}
& x=\frac{\theta}{\lambda}(\sigma-1) \frac{\bar{K}-\theta\left(\frac{(1-\beta)(1-\alpha)}{(1-\gamma) \alpha}+1\right)}{\bar{K}+\theta\left(\frac{(\sigma-1)(1-\beta)(1-\alpha)}{(1-\gamma) \alpha}\right)} . \\
& \cdot\left(\frac{\bar{L}((1-\beta) \sigma(1-\alpha)+(1-\gamma) \alpha)}{\bar{K}(\sigma-(1-\gamma) \alpha-(1-\beta) \sigma(1-\alpha))-\theta(\sigma-1)}\right) .
\end{aligned}
$$

Equations (33) and (34) reveal that capital endowment has a more complicated impact on the price and output solution compared to the exogenous markup case, as an equal increase of both $\bar{K}$ and $\bar{L}$ will no longer offset each other under any circumstances. The implication of this will be examined in terms of how internal economies of scale in this model can be affected by 
globalization. Also notice that the aggregate output quantity $n x$ is also no longer independent of the capital stock $\bar{K}$.

Labor used in the manufacturing final good sector can be derived utilizing the first order conditions of the manufacturing production, such that

$$
L_{m}=n x \lambda\left(\frac{\gamma}{1-\gamma}\right)\left(\frac{1+\sigma(n-1)}{(\sigma-1)(n-1)}\right)
$$

and since the amount of labor employed in the intermediate good sector $L_{I}=n x \lambda$, equation (35) implies that the allocation of labor between manufacturing and intermediate production is no longer solely determined by the parameters of the model, but is also made endogenous. Finally, the remaining variables of the model can be computed analogously to the exogenous markup framework. Thereby the autarkic equilibrium of the model with endogenous markup can be solved for all endogenous variables $n, p, x, r, w, p_{m}, P_{I}, I_{m}, Q_{m}, Q_{s}, L_{I}, L_{m}, L_{s}, K_{s}, U, I$.

The implications of the effect of globalization on external and internal economies in this model evolve as follows. Gains from specialization in the model with endogenous markup are expressed by substituting from (32) and result in

$\mu(n)=\left(\frac{(\sigma-1)(1-\beta)(1-\alpha)}{(1-\beta) \sigma(1-\alpha)+(1-\gamma) \alpha}+\frac{(1-\gamma) \alpha}{\theta} \frac{1}{(1-\beta) \sigma(1-\alpha)+(1-\gamma) \alpha} \bar{K}\right)^{\frac{1}{\rho}-1}$

showing that the external economies of scale in the Dixit-Stiglitz-Ethier model with endogenous markup also depend solely on the capital availability and stay independent of population (i.e. $\frac{\partial \mu}{\partial \bar{K}}>0$ and $\left.\frac{\partial \mu}{\partial \bar{L}}=0\right)$. Again, as the stock of capital is augmented, ceteris paribus, the ratio of fixed to variable costs declines, inducing entry and enhancing specialization. This effect is equivalent to that under an exogenous markup, except that the positive impact on specialization brought about by an increase in the capital stock is more profound. 
The gains from internal economies in this model can be found by utilizing (33) and equal

$$
\begin{aligned}
& v(x)=\frac{\bar{K}-\theta\left(\frac{(1-\beta)(1-\alpha)}{(1-\gamma) \alpha}+1\right)}{\left(\frac{\sigma}{\sigma-1}\right) \bar{K}-\theta} \frac{1}{\lambda} . \\
& \cdot\left(\frac{\bar{L}((1-\beta) \sigma(1-\alpha)+(1-\gamma) \alpha)}{\bar{K}(\sigma-(1-\gamma) \alpha-(1-\beta) \sigma(1-\alpha))-\theta(\sigma-1)}\right)^{1-\beta} .
\end{aligned}
$$

Equation (37) discloses that the internal economies of scale are affected by both capital and labor endowments as in the model with exogenous markup, while they no longer always have a divergent effect. As new firms enter due to market enlargement induced by an additional capital inflow and demand for components gets more elastic, the existing firms lower their prices to capture a larger market share. In Eckel (2004), this effect works through an increase in population, and an increase in the size of the market always enhances both specialization and firm size under endogenous markup.

In this model the final outcome depends on the number of firms active in the equilibrium. As in the model with exogenous markup, an increase in labor endowment would not encourage the entry of new firms in given setup, but support larger firm size. Only additional capital inflow can lead to an enhancement in specialization.

However, as the demand for components gets more elastic, firms can expand both on the account of additional labor and additional capital. In particular, as long as the number of firms in the equilibrium stays rather small, capital augmentation allows firms to enhance any gains from internal economies that can be acquired by an increase in labor availability. It is seen from (37) that the effect of an increase in labor endowment will be the same as in the model with exogenous markup (i.e. $\frac{\partial v}{\partial \bar{L}}>0$ ): as the population grows, ceteris paribus, a larger firm size would be encouraged by an increased demand and by raising the ratio of fixed to variable costs. 
Likewise, $\frac{\partial v}{\partial \bar{K}}>0$, as long as $n<1+\frac{B}{(1-\beta)(\sigma-(1-\gamma) \alpha-(1-\beta) \sigma(1-\alpha))}$, where $B=\frac{w \bar{L}}{w \bar{L}+r \bar{K}}$ is the labor share of total income. Specifically, if the number of firms in operation remains under this threshold, firms benefit from the internal economies of scale irrespective of additional labor availability, as the ratio of fixed to variable costs is higher than in the model with exogenous markup at the same level of endowments. Only when the number of firms reaches $n=1+\frac{B}{(1-\beta)(\sigma-(1-\gamma) \alpha-(1-\beta) \sigma(1-\alpha))}$ will the capital inflow have no influence on firm size (i.e. $\frac{\partial v}{\partial \bar{K}}=0$ ). As the number of firms in the equilibrium grows large, specifically, if it attains $n>1+\frac{B}{(1-\beta)(\sigma-(1-\gamma) \alpha-(1-\beta) \sigma(1-\alpha))}$, then $\frac{\partial v}{\partial \bar{K}}<0$, and the augmentation of capital leads to a decrease in the size of the firm similarly to the model with exogenous markup. Concluding, a small size of the capital stock in the economy will initially allow firms to expand, but as the size of the capital stock increases further, one will reach the exogenous markup solution where the firms will be scaled back as additional capital is utilized for specialization, ceteris paribus. Figure 1 on p. 51 depicts the number of firms' threshold described above for specific parameter values.

Hence capital plays an additionally important role in this endogenous markup framework: it can both enhance the degree of specialization and firm size if the number of firms in the intermediate good sector remains rather small in the equilibrium. If there are already many active component producers present, additional capital inflow will be used to increase specialization and the firm size decreases as the ratio of fixed to variable costs continues to decline. While an increase in population would enhance firm size, a possible simultaneous increase in capital stock 
could work against it, as under exogenous markup. The formation of equilibrium industrial structure is therefore directly dependent on the interaction between internal and external economies in this setup. Proposition 2 summarizes the above discussion.

Proposition 2 If the component producing firms' markup is endogenous and two factors of production are employed, globalization would always increase both specialization and firm size if the number of firms in the industry remains under a specified threshold. As the number of firms increases due to capital inflow, specialization continues to rise, but firm size could either increase or decrease, depending on whether capital or labor stock is augmented more. With many producers in operation, the enlargement motive of firms can only be supported if globalization expands the market through a significant population increase.

Proof Available in the Appendix.

\section{Trade}

Consider next free international trade, induced by globalization-led trade liberalization, taking place between two countries, home and foreign, that are identical in all other respects except possibly their relative factor endowments. In particular, I allow trade in both manufacturing final good $Q_{m}$ and specialized components $x$. In a free trade equilibrium, the output of each component would be concentrated in only one country and the two countries would produce a distinct variety of components, for the same reason that each component is produced by only one firm in autarky (Ethier, 1982). Then the same number of components $n^{*}=n^{h}+n^{f}$ (where superscript $h$ denotes home and $f$ foreign and * relates to the world variable) becomes available to both countries' final manufacturing good sector for intermediate usage. 
It is then apparent, along the lines of Krugman's (1980) modeling of trade in differentiated consumption goods, that domestic residents will exhaust a fraction $\frac{n^{f}}{n^{h}+n^{f}}$ of their income on final manufacturing goods that are composed of foreign components as inputs, whereas foreigners will spend a fraction $\frac{n^{h}}{n^{h}+n^{f}}$ of their income on final manufacturing goods that have made use of home country components. The pattern of component production is determined utilizing the outcome presented in (14) and noting that the residents' total expenditure on domestic manufacturing industry goods is composed of a sum of domestic and foreign residents' expenditures or

$$
n^{h} p^{h} x^{h}=(1-\gamma) \alpha \frac{n^{h}}{n^{h}+n^{f}} I^{h}+(1-\gamma) \alpha \frac{n^{h}}{n^{h}+n^{f}} I^{f}
$$

and since the same reasoning applies towards foreign component production,

$$
n^{f} p^{f} X^{f}=(1-\gamma) \alpha \frac{n^{f}}{n^{h}+n^{f}} I^{h}+(1-\gamma) \alpha \frac{n^{f}}{n^{h}+n^{f}} I^{f}
$$

Dividing (38) by (39) allows to reach, after canceling out $n^{h}$ and $n^{f}, p^{h} x^{h}=p^{f} x^{f}$. Notice that the prices of components equalize in this model through trade, even though prices here are denoted in terms of the non-tradable good. Specifically, as there are no barriers to trade and no transportation costs under consideration, opening up to trade leads to $\frac{p_{m}^{h}}{p^{h}}=\frac{p_{m}^{f}}{p^{f}}$. But $p_{m}^{i}=\frac{1}{\gamma^{\gamma}(1-\gamma)^{1-\gamma}}\left(w^{i}\right)^{\gamma}\left(P_{I}^{i}\right)^{1-\gamma}$ due to competitive pricing, for $i=h, f$, and since the composite price index for the intermediate good becomes the same at the world level, i.e. $P_{I}^{h}=P_{I}^{f}$ (as the intermediate good sector now has $n^{*}=n^{h}+n^{f}$ components available for manufacturing input), the above equalizes component prices (since $p^{i}=\frac{\sigma}{\sigma-1} w^{i} \lambda$ ). As the 
prices of components equalize in trade, this leads to an equalization in the output of specialized intermediate good production or $x^{h}=x^{f}$. Since component prices and outputs equalize across countries, from (11) the equalization in factor prices $(r$ and $w)$ can be observed, a result akin to Markusen (1989). The ability to trade the bundle of intermediate components $I_{m}$ under these circumstances would become redundant.

Equation (38) implies that the number of component-producing firms in operation at the world markets, $n^{h}+n^{f}$, can be expressed analogously to (15), such that in the model with exogenous markup,

$$
n^{h}+n^{f}=\frac{(1-\gamma) \alpha\left(\bar{K}^{h}+\bar{K}^{f}+w^{\frac{1}{1-\beta}}\left(\bar{L}^{h}+\bar{L}^{f}\right)\right)}{\sigma \theta}
$$

After utilizing (16) in two separate equations for domestic and foreign markets and expressing the number of component producing firms at home and abroad $\left(n^{h}\right.$ and $\left.n^{f}\right)$, substitution into (40) allows to solve for the common wage rate as follows:

$$
w^{*}=\left(\frac{\left(\bar{K}^{h}+\bar{K}^{f}\right)(\sigma-(1-\gamma) \alpha-(1-\beta) \sigma(1-\alpha))}{\left(\bar{L}^{h}+\bar{L}^{f}\right)((1-\beta) \sigma(1-\alpha)+(1-\gamma) \alpha)}\right)^{1-\beta}
$$

Equation (41) implies that the internationally equalized wage rate depends on the same parameters as earlier $(\alpha, \beta, \gamma$ and $\sigma)$ and on the factor endowments of both countries. As countries open up to component trade and allow international specialization, the wage rate in a labor-abundant country would increase compared to autarky and the wage rate in a capitalabundant country would decrease (i.e. $w^{h(\text { trade) }}>w^{h(\text { autarky) }}$ if $\frac{\bar{L}^{h}}{\bar{K}^{h}}>\frac{\bar{L}^{f}}{\bar{K}}$ ). This contrasts to the results attained by Chakraborty (2003) in a closely related model, where free trade is able to increase wage rates in both countries, irrespective of labor being a scarce or abundant factor.

A common interest rate in this setup can be found using (9) and it equals 


$$
r^{*}=\left(\frac{\left(\bar{L}^{h}+\bar{L}^{f}\right)((1-\beta) \sigma(1-\alpha)+(1-\gamma) \alpha)}{\left(\bar{K}^{h}+\bar{K}^{f}\right)(\sigma-(1-\gamma) \alpha-(1-\beta) \sigma(1-\alpha))}\right)^{\beta}
$$

implying again that the factor endowments of both countries have an effect on the outcome. In particular, the interest rate in a labor-abundant country would decrease compared to autarky and the interest rate in a capital-abundant country would increase under trade.

Equations (40) and (41) can next be used to derive the expression for the number of component producing firms or the equilibrium degree of specialization at home, which, after several substitutions, results in

$$
\begin{aligned}
& n^{h}=\frac{(1-\gamma) \alpha}{\theta} \frac{1}{(1-\beta) \sigma(1-\alpha)+(1-\gamma) \alpha}\left(\bar{K}^{h}+\bar{K}^{f}\right)+ \\
& +\frac{(1-\alpha)(1-\beta)(\sigma-(1-\gamma) \alpha-(1-\beta) \sigma(1-\alpha))}{\theta((1-\beta) \sigma(1-\alpha)+(1-\gamma) \alpha)} \frac{\bar{L}^{f}\left(\bar{K}^{h}+\bar{K}^{f}\right)}{\left(\bar{L}^{h}+\bar{L}^{f}\right)}- \\
& -\frac{(\alpha+\beta-\alpha \beta) \bar{K}^{f}}{\theta} .
\end{aligned}
$$

Equation (43) reveals that the number of components produced no longer solely depends on the parameter values and domestic capital endowment. In fact, even though $\frac{\partial n^{h}}{\partial \bar{K}^{h}}>0$ as in autarky, it follows from (43) that $\frac{\partial n^{h}}{\partial \bar{K}^{h}}>0, \frac{\partial n^{h}}{\partial \bar{L}^{h}}<0$ and $\frac{\partial n^{h}}{\partial \bar{L}^{f}}>0$. Then an increase in the capital endowment in another country hinders domestic horizontal specialization, while an enlargement in labor endowment abroad encourages it. A population increase at home also discourages specialization, as it raises the ratio of fixed to variable costs. The solution for the equilibrium number of firms abroad, $n^{f}$, is a mirror image of (43), achieved by replacing the superscript $h$ by $f$ and $f$ by $h$.

Next, the solution for the price and output of produced components can be derived analogous to autarky by making use of (10) and (11), which leads to 


$$
p^{*}=\frac{\sigma}{\sigma-1} \lambda\left(\frac{\left(\bar{K}^{h}+\bar{K}^{f}\right)(\sigma-(1-\gamma) \alpha-(1-\beta) \sigma(1-\alpha))}{\left(\bar{L}^{h}+\bar{L}^{f}\right)((1-\beta) \sigma(1-\alpha)+(1-\gamma) \alpha)}\right)^{1-\beta}
$$

and

$$
x^{*}=\frac{\theta}{\lambda}(\sigma-1)\left(\frac{\left(\bar{L}^{h}+\bar{L}^{f}\right)((1-\beta) \sigma(1-\alpha)+(1-\gamma) \alpha)}{\left(\bar{K}^{h}+\bar{K}^{f}\right)(\sigma-(1-\gamma) \alpha-(1-\beta) \sigma(1-\alpha))}\right) .
$$

Equations (44) and (45) show results very similar to the autarky model under exogenous markup, except that both the price and output of the specialized components are dependent on worldwide labor and capital endowments. Compared to autarky, the price of the components would increase and the output of each component would fall in the labor-abundant country. The opposite would occur in the capital-abundant country. Also notice that the world aggregate output quantity of all stages of production $\left(n^{h}+n^{f}\right) x$ has a complicated solution and will depend on population and capital stocks in both countries.

The effect of trade on specialization in this model evolves from comparing the equilibrium number of firms operating in component production under trade with the same variable under autarky. Subtracting (19) from (43) and some manipulation results in $n^{h(\text { trade) }}>n^{\text {(autarky) }}$ if $\frac{\bar{L}^{f}}{\bar{K}^{f}}>\frac{\bar{L}^{h}}{\bar{K}^{h}}$. It then follows that horizontal specialization increases in the capital-abundant country relative to autarky and decreases in the labor-abundant country. Notice that the total number of firms that produce components in the world remains the same as before trade. Then when trade opens up and countries do not differ in their relative factor endowments, each of them would continue to produce exactly the same number of components as in autarky. The fact that the pattern of production stays unchanged forms a basis for a well-known result on horizontal intra-industry trade under monopolistic competition, in that similar countries are the ones to engage in such trade, as in Krugman (1981). 
In order to determine the direction of trade, it is left to analyze the balance of payments. Again, analogous to Krugman (1980), the home country trade balance for components is specified by $C=\frac{n^{h}}{n^{h}+n^{f}}(1-\gamma) \alpha I^{f}-\frac{n^{f}}{n^{h}+n^{f}}(1-\gamma) \alpha I^{h}=n^{h} p^{*} x^{*}-\frac{n^{h}}{n^{h}+n^{f}}$. $\cdot(1-\gamma) \alpha I^{h}-\frac{n^{f}}{n^{h}+n^{f}}(1-\gamma) \alpha I^{h}=n^{h} p^{*} x^{*}-(1-\gamma) \alpha I^{h}$. Then it ensues after some manipulation that $n^{h} p^{*} x^{*}>(1-\gamma) \alpha I^{h}$ if and only if $\frac{\bar{L}^{f}}{\bar{K}^{f}}>\frac{\bar{L}^{h}}{\bar{K}^{h}}$. Notice in addition that the total demand for the final manufacturing good at home is given by $\alpha I^{h}$. Then for balanced trade one needs the capital-abundant home country to contribute less labor into manufacturing assembly than would be the case in autarky, given the number of components produced domestically. ${ }^{4}$ In particular, I verify that $w^{*} L_{m}^{h}<\gamma \alpha I^{h}$ if and only if $\frac{\bar{L}^{f}}{\bar{K}^{f}}>\frac{\bar{L}^{h}}{\bar{K}^{h}}$. As a result a balanced trade between specialized components and the final manufacturing good develops.

Proposition 3 Free trade in intermediate components and the final manufacturing good between two countries that are identical in all other respects than their factor endowments will increase horizontal specialization in a relatively capital-abundant country and decrease it in a relatively labor-abundant country. The direction of trade will be such that the capital-abundant country will become a net exporter of components and an importer of the final good.

\section{Proof Available in the Appendix.}

Notice how horizontal intra-industry trade in components and trade across the stages of production interact in this model. While the incentive for trade is triggered by a larger number of

\footnotetext{
4 This implies that the relationship specified in (22) would no longer hold, i.e. $L_{m}{ }^{h} \neq n^{h} x^{*} \lambda\left(\frac{\gamma}{1-\gamma}\right)\left(\frac{\sigma}{\sigma-1}\right)$ as can be shown by contradiction.
} 
intermediate components becoming available, it is the endowment basis that determines specialization and trade pattern. In particular, if two countries would be similar and increasing returns would form the basis for trade, both countries would continue to produce exactly the same number of components as in autarky, simply producing a larger output of each component - and the direction of trade would be indeterminate (one would not know which country would produce which components, as in Krugman, 1980). The volume of trade in components occurring due to increasing returns in such a case could, however, be specified by $\frac{n^{f}}{n^{h}+n^{f}}(1-\gamma) \alpha I^{h}$, and balanced trade in specialized components would hold, so that trade in $Q_{m}$ would be redundant.

Finally, since the prices and outputs of specialized components are equalized across countries, the expression for the total world output of intermediate goods evolves into $I_{m}^{*}=x^{*}\left(n^{h\left(\frac{1}{\rho} \frac{\sigma}{\sigma-1}\right)}+n^{f\left(\frac{1}{\rho} \frac{\sigma}{\sigma-1}\right)}\right)^{\frac{\sigma}{\sigma-1}}$ and the respective composite price index becomes $P_{I}^{*}=p^{*}\left(n^{h\left(\frac{\sigma-1}{\rho}-\sigma+1\right)}+n^{f\left(\frac{\sigma-1}{\rho}-\sigma+1\right)}\right)^{\frac{1}{1-\sigma}}$.

Lemma 1 Free trade in specialized components requires that $\rho=\frac{\sigma-1}{\sigma}$.

\section{Proof Available in the Appendix.}

If $\rho=\frac{\sigma-1}{\sigma}$, then the total world output in the intermediate good sector becomes $I_{m}^{*}=\left(n^{h}+n^{f}\right)^{\frac{1}{\rho}} X^{*}$ and the composite price index solves for $P_{I}^{*}=\left(n^{h}+n^{f}\right)^{1-\frac{1}{\rho}} p^{*}$. Each country will contribute a share $\frac{n^{i}}{n^{h}+n^{f}}, i=h, f$, to the total value of the intermediate good 
production $P_{I}^{*} I_{m}{ }^{*}$ in the world. Even though the direction and the volume of trade can be determined in this model, as well as how much labor in each country is employed in the intermediate good and manufacturing sectors $\left(L_{I}{ }^{i}\right.$ and $\left.L_{m}{ }^{i}\right)$, it is not possible to disclose which country produces how much of the world supply of the final manufacturing good $Q_{m}{ }^{*} \cdot{ }^{5}$ It is still known that $Q_{m}{ }^{*}=\left(L_{m}{ }^{*}\right)^{\gamma}\left(I_{m}{ }^{*}\right)^{1-\gamma}$, where ${L_{m}}^{*}=\left(n^{h}+n^{f}\right) x^{*} \lambda\left(\frac{\gamma}{1-\gamma}\right)\left(\frac{\sigma}{\sigma-1}\right)$.

Finally, the effect of an adjustment in factor endowments on internal economies in the model with exogenous markup under free trade is equivalent to what was derived in autarky, while the effect on external economies is determined by (43), revealing a much more complex result than was reached earlier, as external economies now can be influenced by an amendment in capital and labor endowments both at home and abroad.

The implications of component trade in a model with endogenous markup can be examined analogously. One can utilize equations (38) and (29) to reach

$$
n^{h}+n^{f}=\frac{(1-\gamma) \alpha\left(\bar{K}^{h}+\bar{K}^{f}+w^{\frac{1}{1-\beta}}\left(\bar{L}^{h}+\bar{L}^{f}\right)\right)+\theta(\sigma-1)}{\sigma \theta}
$$

and make use of (16) to derive, after substitution, the common wage and interest rates as earlier, which equal

5 Therefore notice the flaw in the approach undertaken by Chakraborty (2003) in a similar model. His equation (33) expresses the world supply of the good since from (32) the intermediate input is the same for both countries. In particular, his $L_{y}=L_{y}{ }^{h}+L_{y}{ }^{f}=\frac{1-\alpha}{1-\alpha+\alpha \rho}\left(L^{h}+L^{f}\right)$. In that model $L_{y}{ }^{f}=L^{f}-\frac{\alpha \rho}{1-\alpha+\alpha \rho} \frac{\left(L^{h}+L^{f}\right)}{\left(K^{h}+K^{f}\right)} K^{f}$ as derived in his (38), if one notices that $\rho=\frac{\sigma-1}{\sigma}$ is used interchangeably. But $L_{y}{ }^{f}=L^{f}-\frac{\alpha \rho}{1-\alpha+\alpha \rho} \frac{\left(L^{h}+L^{f}\right)}{\left(K^{h}+K^{f}\right)} K^{f} \neq \frac{1-\alpha}{1-\alpha+\alpha \rho} L^{f}$ unless $\frac{L^{f}}{K^{f}}=\frac{L^{h}}{K^{h}}$, which would make the setup in his (41) and the conclusion reached in (43) inapplicable. 


$$
w^{*}=\left(\frac{\left(\bar{K}^{h}+\bar{K}^{f}\right)(\sigma-(1-\gamma) \alpha-(1-\beta) \sigma(1-\alpha))-\theta(\sigma-1)}{\left(\bar{L}^{h}+\bar{L}^{f}\right)((1-\beta) \sigma(1-\alpha)+(1-\gamma) \alpha)}\right)^{1-\beta}
$$

and

$$
r^{*}=\left(\frac{\left(\bar{L}^{h}+\bar{L}^{f}\right)((1-\beta) \sigma(1-\alpha)+(1-\gamma) \alpha)}{\left(\bar{K}^{h}+\bar{K}^{f}\right)(\sigma-(1-\gamma) \alpha-(1-\beta) \sigma(1-\alpha))-\theta(\sigma-1)}\right)^{\beta} .
$$

Equations (47) and (48) show that opening up to trade would increase the wage rate and decrease the interest rate in a labor-abundant country, but not as much as under exogenous markup. The additional term as expressed by $\theta(\sigma-1)$ has a negative impact on the equilibrium wage level, making labor cheaper, and a positive impact on the equilibrium interest rate, making capital more expensive. Therefore the equilibrium wage rate in both countries would be lower than what was derived in (41) and the equilibrium interest rate higher than in (42). However, since in autarky the difference in factor prices is larger under endogenous markup given the same factor endowments, the model implies that trade will increase the wage rate and decrease the interest rate in a labor-abundant country relatively more than in the exogenous markup setup. As before, a relatively capital-abundant country would experience a decrease in the wage rate and an increase in the interest rate.

The equilibrium degree of specialization in the model with endogenous markup solves from (46) and (47) and results for the home country in

$$
\begin{aligned}
& n^{h}=\frac{(\sigma-1)(1-\beta)(1-\alpha)}{(1-\beta) \sigma(1-\alpha)+(1-\gamma) \alpha}+\frac{(1-\gamma) \alpha}{\theta} . \\
& \cdot \frac{1}{(1-\beta) \sigma(1-\alpha)+(1-\gamma) \alpha}\left(\bar{K}^{h}+\bar{K}^{f}\right)+ \\
& +\frac{(1-\alpha)(1-\beta)(\sigma-(1-\gamma) \alpha-(1-\beta) \sigma(1-\alpha))}{\theta((1-\beta) \sigma(1-\alpha)+(1-\gamma) \alpha)} \frac{\left.\bar{L}^{f} \bar{K}^{h}+\bar{K}^{f}\right)}{\left(\bar{L}^{h}+\bar{L}^{f}\right)}- \\
& -\frac{(\alpha+\beta-\alpha \beta) \bar{K}^{f}}{\theta} .
\end{aligned}
$$


Equation (49) discloses that the effect from trade on the number of firms operating in component production under endogenous markup parallels that reached in (43) and is larger by the first term. Finally, noticing that the price elasticity of demand is now equal to $\frac{\partial x_{j}^{*}}{\partial p_{j}{ }^{*}} \frac{p_{j}{ }^{*}}{x_{j}{ }^{*}}=-\sigma+\frac{1}{n^{h}+n^{f}}(\sigma-1)$, which implies that the price of a component can be expressed by $p^{*}=\left(\frac{1}{\sigma-1}\left(\sigma+\frac{1}{n^{h}+n^{f}-1}\right)\right) w^{*} \lambda$, one can solve for the price and output of the component producing sector. In particular,

$$
\begin{aligned}
& p^{*}=\lambda \frac{\left(\frac{\sigma}{\sigma-1}\right)\left(\bar{K}^{h}+\bar{K}^{f}\right)-\theta}{\left(\bar{K}^{h}+\bar{K}^{f}\right)-\theta\left(\frac{(1-\beta)(1-\alpha)}{(1-\gamma) \alpha}+1\right)} \cdot \\
& \cdot\left(\frac{\left(\bar{K}^{h}+\bar{K}^{f}\right)(\sigma-(1-\gamma) \alpha-(1-\beta) \sigma(1-\alpha))-\theta(\sigma-1)}{\left(\bar{L}^{h}+\bar{L}^{f}\right)((1-\beta) \sigma(1-\alpha)+(1-\gamma) \alpha)}\right)^{1-\beta}
\end{aligned}
$$

and

$$
\begin{gathered}
x^{*}=\frac{\theta}{\lambda}(\sigma-1) \frac{\left(\bar{K}^{h}+\bar{K}^{f}\right)-\theta\left(\frac{(1-\beta)(1-\alpha)}{(1-\gamma) \alpha}+1\right)}{\left(\bar{K}^{h}+\bar{K}^{f}\right)+2 \theta\left(\frac{(\sigma-1)(1-\beta)(1-\alpha)}{(1-\gamma) \alpha}\right)} \\
\cdot\left(\frac{\left(\bar{L}^{h}+\bar{L}^{f}\right)((1-\beta) \sigma(1-\alpha)+(1-\gamma) \alpha)}{\left(\bar{K}^{h}+\bar{K}^{f}\right)(\sigma-(1-\gamma) \alpha-(1-\beta) \sigma(1-\alpha))-\theta(\sigma-1)}\right)
\end{gathered}
$$

Equations (50) and (51) reveal a similar outcome to the autarky model, except that now the factor endowments of both countries play a role. The results for the pattern of horizontal specialization and the direction of trade in the model with endogenous markup parallel those reached under exogenous markup. The effect of an adjustment in factor endowments on internal economies in the model with endogenous markup under free trade is equivalent to what was 
derived in autarky, while the effect on external economies is determined by (49), implying a result that parallels the one reached in the exogenous markup model under free trade.

Finally, I derive the welfare implications of trade. Since factor prices change in opposite directions, there exist divergent effects for countries differing in their capital-labor ratios when countries open up for trade. In particular, a relatively labor-abundant country would gain from an increase in the wage rate, but lose from a decrease in the interest rate as a result of trade. $A$ relatively capital-abundant country would on the other hand gain from an increase in the interest rate and lose from a decrease in the wage rate. The resulting outcome on total income will therefore depend on which effect dominates. Since national income in the economy is given by $I=w \bar{L}+r \bar{K}$, the change in income in proportional terms can be expressed by $\hat{I}=\Theta_{L} \hat{w}+\Theta_{K} \hat{r}$ (assuming there is no change in endowments), where $\Theta_{L}=\frac{w \bar{L}}{I}$ and $\Theta_{K}=\frac{r \bar{K}}{I}$. Notice that the proportional change in the home interest rate under exogenous markup can be calculated to equal $\hat{r}=\left(\frac{\bar{L}^{h}+\bar{L}^{f}}{\bar{K}^{h}+\bar{K}^{f}}\right)^{\beta} \cdot\left(\frac{\bar{K}^{h}}{\bar{L}^{h}}\right)^{\beta}-1$, whereas the proportional change in the home wage rate is $\widehat{w}=\left(\frac{\bar{K}^{h}+\bar{K}^{f}}{\bar{L}^{h}+\bar{L}^{f}}\right)^{1-\beta} \cdot\left(\frac{\bar{L}^{h}}{\bar{K}^{h}}\right)^{1-\beta}-1.6$ It is then clear that the trade-off between the income change accruing from the interest rate and the wage rate will depend on the parameter value $\beta$ (the factor share of labor in non-tradable good

$$
\begin{aligned}
& 6 \text { The proportional change in the home interest rate under endogenous markup is } \\
& \hat{r}=\left(\frac{\bar{L}^{h}+\bar{L}^{f}}{\bar{L}^{h}}\right)^{\beta} \cdot\left(\frac{\bar{K}^{h}(\sigma-(1-\gamma) \alpha-(1-\beta) \sigma(1-\alpha))-\theta(\sigma-1)}{\left(\bar{K}^{h}+\bar{K}^{f}\right)(\sigma-(1-\gamma) \alpha-(1-\beta) \sigma(1-\alpha))-\theta(\sigma-1)}\right)^{\beta}-1 \quad \text { and the proportional } \\
& \text { change in the home rage equals } \\
& \hat{w}=\left(\frac{\bar{L}^{h}}{\bar{L}^{h}+\bar{L}^{f}}\right)^{1-\beta} \cdot\left(\frac{\left(\bar{K}^{h}+\bar{K}^{f}\right)(\sigma-(1-\gamma) \alpha-(1-\beta) \sigma(1-\alpha))-\theta(\sigma-1)}{\bar{K}^{h}(\sigma-(1-\gamma) \alpha-(1-\beta) \sigma(1-\alpha))-\theta(\sigma-1)}\right)^{1-\beta}-1 .
\end{aligned}
$$


output) and how much the domestic relative factor endowment differs from the foreign one. When markup is endogenous, also the parameter values of $\alpha, \gamma, \sigma$ and $\theta$ have an impact, such that the wage rate would increase more and the interest rate decrease more for a relatively laborabundant country. For a relatively capital-abundant country however the wage rate (interest rate) would not decrease (increase) as much as under exogenous markup.

Figure 2 on p. 52 represents some possible welfare outcomes, where an increase in the welfare results for all the function's values higher than zero and a decrease otherwise. Relative factor abundance ratios for capital-abundant and labor-abundant countries are from Romalis (2004); the left panel of the figure depicts averages for North and South and the right panel minimum and maximum values (factor abundance is relative to the U.S.). In general, a laborabundant country is likely to gain from trade at lower values of $\beta$, while a capital-abundant country at more realistic higher values of $\beta$. The more dissimilar the countries are in their capitallabor ratios, the more both countries can gain or lose. However, there also exists a range for $\beta$, for which both countries are able to gain from trade and for which the welfare gain of a laborabundant country exceeds that of a capital-abundant country. Also observe that the welfare of a relatively capital-abundant country is not much influenced by changes in factor abundance, while that of a relatively labor-abundant country is, since it experiences more significant adjustment in factor prices as a result of trade.

\section{$5 \quad$ Conclusions}

This paper has analyzed how globalization, through the enlargement of the market, can affect both specialization and the equilibrium firm size within the framework of monopolistic competition incorporating two factors of production. This paper also determined how the pattern 
of trade across the stages of production evolved between countries that differ in their relative factor endowments.

I developed a three-sector model of final, intermediate and non-tradable goods, incorporating costly assembly and increasing returns, to study the interaction between internal and external economies and their subsequent impact on the formation of equilibrium industrial structure. Compared to the much-utilized one factor of production costless-assembly DixitStiglitz-Ethier framework, significant differences emerged.

I showed that with two factors of production employed in the monopolistically competitive intermediate good sector, only an increase in the capital stock could enhance horizontal specialization, whereas only an increase in population was able to induce larger firm size. As the size of the market is determined by total income, a globalization-driven market enlargement can occur because of capital and/or labor inflow. Then globalization would always increase specialization and it could either increase, decrease or not affect the size of the firm, depending on how much capital augmentation is able to offset that of labor as the market enlarges.

I next endogenized the markup in the model as a function of the intermediate good industry's degree of specialization in order to study the importance of the price-index effect. This setup allowed to demonstrate that globalization would always increase both specialization and firm size if the number of producers in the intermediate good industry remained under a specified threshold. If the number of component producers would increase above this threshold due to capital inflow, specialization would rise, but the size of the firm could either increase or decrease, depending on whether capital or labor stock is augmented more, as in the case with exogenous markup. With many producers in operation, the enlargement motive of the firms could only be supported if globalization expands the market through a significant population increase. 
When the size of the market expanded through trade, I showed that free trade in intermediate inputs and a final consumption good would equalize factor prices and that the endowment basis determined the direction of trade across the stages of production. Accordingly, a relatively capital-abundant country would become a net exporter of components and an importer of the final manufacturing good under both exogenous and endogenous markups. Compared to autarky, trade would enhance horizontal specialization and firm size in the capitalabundant country and diminish them in the labor-abundant country. I also demonstrated that welfare can either increase or decrease as a result of trade, whereas both countries are likely to gain when they are very dissimilar in their capital-labor ratios. 


\section{References}

1. Antras, P. and E. Helpman (2004). "Global sourcing", Journal of Political Economy, 112, 552-580.

2. Batra, R.N. and F. Casas (1973). "Intermediate products and the pure theory of international trade: A neo-Heckscher-Ohlin framework", American Economic Review, 63, 297-311.

3. Bergoeing, R., T. Kehoe, V. Strauss-Kahn and K.-M. Yi (2004). "Why is manufacturing trade rising even as manufacturing output is falling?", American Economic Review, 94, 134-138.

4. Chakraborty, B.S. (2003). "Trade in intermediate goods in a model with monopolistic competition", Economica, 70, 551-566.

5. Chipman, J. (1970). "External economies of scale and competitive equilibrium", Quarterly Journal of Economics, 84, 347-385.

6. d'Aspremont, C., R. Dos Santos Ferreira and L.-A. Gerard-Varet (1996). "On the Dixit-Stiglitz model of monopolistic competition”, American Economic Review, 86, 623-629.

7. Deardorff, A. (2001). "Fragmentation in simple trade models", North American Journal of Economics and Finance, 12, 121-137.

8. Dixit, A.K. and J.E. Stiglitz (1977). "Monopolistic competition and optimum product diversity", American Economic Review, 67, 297-308.

9. Eckel, C. (2004). "Globalization and specialization", University of Göttingen mimeo.

10. Egger, H. and P. Egger (2001). "Cross-border sourcing and outward processing in EU manufacturing", North American Journal of Economics and Finance, 12, 243-256.

11. Ethier, W. (1986). "The multinational firm”, Quarterly Journal of Economics, 80, 805-833.

12. Ethier, W. (1982). "National and international returns to scale in the modern theory of international trade", American Economic Review, 72, 389-405.

13. Evenett, S.J. (2003). "The cross-border mergers and acquisitions wave of the late 1990s", NBER Working Paper 9655.

14. Feenstra, R. (1998). "Integration of trade and disintegration of production in the global economy", Journal of Economic Perspectives, 12, 31-50.

15. Feenstra, R. and G. Hanson (1996). "Globalization, outsourcing, and wage inequality", American Economic Review, 86, 240-245.

16. Francois, J. and D. Nelson (1998). "A geometry of specialization", Centre for International Economic Studies, University of Adelaide, Seminar Paper 98-01. 
17. Gerber, J. (2000). "Maquiladoras in transition: It's not just cheap labor anymore", Cross-border Economic Bulletin.

18. Grossman, G. and E. Helpman (2002a). "Integration versus outsourcing in industry equilibrium", Quarterly Journal of Economics, 117, 85-120.

19. Grossman, G. and E. Helpman (2005). "Outsourcing in a global economy", Review of Economic Studies, 72, 135-159.

20. Grossman, G. and E. Helpman (2002b). "Outsourcing versus FDI in industry equilibrium", Journal of the European Economic Association, 1, 317-327.

21. Hanson, G., R. Mataloni and M. Slaughter (2004). "Vertical production networks in multinational firms", NBER Working Paper 9723.

22. Helpman, E. (1984). "A simple theory of international trade with multinational corporations", Journal of Political Economy, 92, 451-471.

23. Helpman, E. and P. Krugman (1985). Market structure and foreign trade: Increasing returns, imperfect competition, and the international economy (The MIT Press).

24. Hummels, D., J. Ishii and K.-M. Yi (2001). "The nature and growth of vertical specialization in world trade", Journal of International Economics, 54, 75-96.

25. Hummels, D., D. Rapoport and K.-M. Yi (1998). "Vertical specialization and the changing nature of world trade", Federal Reserve Bank of New York Economic Policy Review.

26. Jones, R. (1965). "The structure of simple general equilibrium models", Journal of Political Economy, $73,557-572$.

27. Kandogan, Y. (2003). "Intra-industry trade of transition countries: Trends and determinants", William Davidson Institute Working Paper 566.

28. Krugman, P. (1981). "Intra-industry specialization and the gains from trade", Journal of Political Economy, 89, 959-973.

29. Krugman, P. (1980). "Scale economies, product differentiation, and the pattern of trade", American Economic Review, 70, 950-959.

30. Kumar, K., R. Rajan and L. Zingales (2001). "What determines firm size?", GSB University of Chicago mimeo.

31. Liu, P.-W. and X. Yang (2000). "The theory of irrelevance of the size of the firm", Journal of Economic Behavior and Organization, 42, 145-165.

32. Markusen, J. (1995). "The boundaries of multinational enterprises and the theory of international 
trade", Journal of Economic Perspectives, 9, 169-189.

33. Markusen, J. (1990). "Micro-foundations of external economies", Canadian Journal of Economics, 23, 494-508.

34. Markusen, J. (1982). "Multinationals, multi-plant economies, and the gains from trade", Journal of International Economics, 16, 205-226.

35. Markusen, J. (1989). "Trade in producer services and in other specialized intermediate inputs", American Economic Review, 79, 85-95.

36. Markusen, J. and J. Melvin (1981). "Trade, factor prices, and the gains from trade with increasing returns to scale", Canadian Journal of Economics, 14, 450-469.

37. Markusen, J., T.F. Rutherford and D. Tarr (2000). "Trade and direct investment in producer services and the domestic market for expertise", NBER Working Paper 7700, Canadian Journal of Economics, forthcoming.

38. Markusen, J. and A. Venables (2000). "The theory of endowment, intra-industry and multi-national trade", Journal of International Economics, 52, 209-234.

39. Neary, J.P. (2003a). "Globalization and market structure", Journal of the European Economic Association, 1, 245-271.

40. Neary, J.P. (2003b). "Monopolistic competition and international trade theory", in The Monopolistic Competition Revolution in Retrospect (eds.) S. Brakman, B.J. Heijdra (Cambridge University Press).

41. Neary, J.P. (2003c). "The road less traveled: oligopoly and competition policy in general equilibrium", in Economics for an Imperfect World: Essays in Honor of Joseph Stiglitz (eds.) R. Arnott, B. Greenwald, R. Kanbur, B. Nalebuff (The MIT Press).

42. Ng, F. and A. Yeats (1999). "Production sharing in East Asia: Who does what for whom and why?", World Bank mimeo.

43. Prahalad, C.K. and G. Hamel (1990). "The core competence of the corporation", Harvard Business Review, 68, 79-91.

44. Rajan, R. and L. Zingales (1998). "Financial dependence and growth", American Economic Review, $88,559-586$.

45. Redding, S. (2002). "Specialization dynamics", Journal of International Economics, 58, 299-334.

46. Rivera-Batiz, F.L. and L.A. Rivera-Batiz (1991). "The effects of direct foreign investment in the presence of increasing returns due to specialization", Journal of Development Economics, 34, 287307. 
47. Romalis, J. (2004). "Factor proportions and the structure of commodity trade", American Economic Review, 94, 67-97.

48. Slaughter, M. (2000). "Production transfer within multinational enterprises and American wages", Journal of International Economics, 50, 449-472.

49. Sturgeon, T. (2002). "Exploring the risks of value chain modularity: Electronics outsourcing during the industry cycle of 1992-2002", MIT Industrial Performance Center Working Paper MIT-IPC-03-003.

50. Venables, A. (1999). "Fragmentation and multinational production", European Economic Review, 43, 935-945.

51. Venables, A. (1996). "Trade policy, cumulative causation, and industrial development", Journal of Development Economics, 49, 179-197.

52. Yang, X. and B. Heijdra (1993). "Monopolistic competition and optimum product diversity: Comment", American Economic Review, 83, 295-301.

53. Yi, K.-M. (2003). "Can vertical specialization explain the growth of world trade?", Journal of Political Economy, 111, 52-102. 


\section{Appendix}

Proof of $\sigma-(1-\gamma) \alpha-(1-\beta) \sigma(1-\alpha)>0$

This proof relates to the variable solutions in the model with exogenous markup, in particular, it shows that (17), (18), (20), (21) and (24) are positive.

Since $\sigma-(1-\gamma) \alpha-(1-\beta) \sigma(1-\alpha)=\sigma(1-(1-\beta)(1-\alpha))-(1-\gamma) \alpha$ is increasing in $\sigma$ and $\sigma>1$, this expression achieves its minimum at $\sigma \rightarrow 1$. Rewrite the above with $\sigma=1$ to reach $1-(1-\beta)(1-\alpha)-(1-\gamma) \alpha=\beta(1-\alpha)+\alpha \gamma>0$.

Proof of $\left(\frac{\sigma}{\sigma-1}\right) \bar{K}-\theta>0$

This and all the remaining proofs of positive expressions relate to the model with endogenous markup, in particular, they show that (30), (31), (33), (34) and (37) are positive.

From the capital full employment condition in (7), $\bar{K}>n \theta$; then substitute for $n$ utilizing (32) to reach, after some manipulation, $\sigma \bar{K}>\theta(\sigma-1)$.

Proof of $\bar{K}(\sigma-(1-\gamma) \alpha-(1-\beta) \sigma(1-\alpha))-\theta(\sigma-1)>0$

Rewrite $(1-\gamma) \alpha$ using (14) and (28) to reach $(1-\gamma) \alpha=\frac{n \theta r \sigma-r \theta(\sigma-1)}{I}$, and $(1-\alpha)(1-\beta)$ after substituting from (8) and the solution to the utility maximization $Q_{s}=(1-\alpha) I$ to reach $(1-\alpha)(1-\beta)=\frac{K_{s} r}{I}$. Also notice that from $(7), K_{s}=\bar{K}-n \theta$ and that total income in the economy $I=w \bar{L}+r \bar{K}$. Then $\sigma-(1-\gamma) \alpha-(1-\beta) \sigma(1-\alpha)=\sigma\left(1-\frac{r \bar{K}}{w \bar{L}+r \bar{K}}\right)+\frac{r \theta(\sigma-1)}{w \bar{L}+r \bar{K}}$ and $\bar{K}(\sigma-(1-\gamma) \alpha-(1-\beta) \sigma(1-\alpha))-\theta(\sigma-1)=\bar{K} \sigma\left(1-\frac{r \bar{K}}{w \bar{L}+r \bar{K}}\right)+\frac{\bar{K} r \theta(\sigma-1)}{w \bar{L}+r \bar{K}}-$ $-\theta(\sigma-1)=\bar{K} \sigma\left(1-\frac{r \bar{K}}{w \bar{L}+r \bar{K}}\right)-\theta(\sigma-1)\left(1-\frac{r \bar{K}}{w \bar{L}+r \bar{K}}\right)=\left(\frac{w \bar{L}}{w \bar{L}+r \bar{K}}\right)(\sigma \bar{K}-\theta(\sigma-1))>$ $>0$, since the last term is positive from the proof above and $0<B<1$, where $B=\frac{w \bar{L}}{w \bar{L}+r \bar{K}}$ is the labor share of income. 
Proof of $\bar{K}-\theta\left(\frac{(1-\beta)(1-\alpha)}{(1-\gamma) \alpha}+1\right)>0$

Notice that $\frac{(1-\beta)(1-\alpha)}{(1-\gamma) \alpha}=\frac{\bar{K}-n \theta}{n \theta \sigma-\theta(\sigma-1)}$ and after substituting this into the expression above, it becomes $\bar{K}-\theta\left(\frac{(1-\beta)(1-\alpha)}{(1-\gamma) \alpha}+1\right)=\bar{K}-\theta\left(\frac{\bar{K}-n \theta}{n \theta \sigma-\theta(\sigma-1)}+1\right)$, yielding, after some manipulation, $\bar{K}-\theta\left(\frac{(1-\beta)(1-\alpha)}{(1-\gamma) \alpha}+1\right)=\frac{\sigma \bar{K}-\theta(\sigma-1)}{\sigma+\frac{1}{n-1}}>0$.

\section{Proof of Proposition 2}

To prove Proposition 2, one needs to show that the sign of the derivative of internal economies with respect to $\bar{K}$ is dependent on the number of firms operating in the intermediate good industry.

The derivative of internal economies expressed by (37) with respect to $\bar{K}$ is equal to

$$
\begin{aligned}
& \frac{\partial v}{\partial \bar{K}}=\frac{1}{\lambda}\left(\frac{1}{\left(\frac{\sigma}{\sigma-1}\right) \bar{K}-\theta}-\frac{\bar{K}-\theta\left(\frac{(1-\beta)(1-\alpha)}{(1-\gamma) \alpha}+1\right)}{\left(\left(\frac{\sigma}{\sigma-1}\right) \bar{K}-\theta\right)^{2}}\left(\frac{\sigma}{\sigma-1}\right)\right) \\
& \cdot\left(\frac{\bar{L}((1-\beta) \sigma(1-\alpha)+(1-\gamma) \alpha)}{\bar{K}(\sigma-(1-\gamma) \alpha-(1-\beta) \sigma(1-\alpha))-\theta(\sigma-1)}\right)^{1-\beta}+\frac{1}{\lambda} \frac{\bar{K}-\theta\left(\frac{(1-\beta)(1-\alpha)}{(1-\gamma) \alpha}+1\right)}{\left(\frac{\sigma}{\sigma-1}\right) \bar{K}-\theta} . \\
& \cdot(\bar{L}((1-\beta) \sigma(1-\alpha)+(1-\gamma) \alpha))^{1-\beta}(-1)(1-\beta) \cdot \\
& \cdot \frac{\sigma-(1-\gamma) \alpha-(1-\beta) \sigma(1-\alpha)}{(\bar{K}(\sigma-(1-\gamma) \alpha-(1-\beta) \sigma(1-\alpha))-\theta(\sigma-1))^{2-\beta}} .
\end{aligned}
$$

To determine the sign of this derivative I collect common positive terms and substitute to reach

$$
\begin{aligned}
& \frac{\partial v}{\partial \bar{K}}=\left(\frac{\sigma+\frac{1}{n-1}}{\sigma \bar{K}-\theta(\sigma-1)}-\frac{\sigma}{\sigma \bar{K}-\theta(\sigma-1)}-(1-\beta) \frac{\sigma-(1-\gamma) \alpha-(1-\beta) \sigma(1-\alpha)}{B(\sigma \bar{K}-\theta(\sigma-1))}\right) . \\
& \cdot \frac{1}{\lambda} \frac{\bar{K}-\theta\left(\frac{(1-\beta)(1-\alpha)}{(1-\gamma) \alpha}+1\right)}{\left(\frac{\sigma}{\sigma-1}\right) \bar{K}-\theta}\left(\frac{\bar{L}((1-\beta) \sigma(1-\alpha)+(1-\gamma) \alpha)}{\bar{K}(\sigma-(1-\gamma) \alpha-(1-\beta) \sigma(1-\alpha))-\theta(\sigma-1)}\right)^{1-\beta}=
\end{aligned}
$$


$=\left(\frac{1}{n-1}-(1-\beta) \frac{1}{B}(\sigma-(1-\gamma) \alpha-(1-\beta) \sigma(1-\alpha))\right) \frac{v}{(\sigma \bar{K}-\theta(\sigma-1))}$. From this expression it clearly follows that the last multiplicative term of the derivative is positive and will therefore not influence the sign. Hence I need to show what sign $\frac{1}{n-1}-(1-\beta) \frac{1}{B}(\sigma-(1-\gamma) \alpha-(1-\beta) \sigma(1-\alpha))$ has.

As $\quad \lim _{n \rightarrow \infty}, \quad \frac{\partial v}{\partial \bar{K}}<0, \quad$ since $\quad-(1-\beta) \frac{1}{B}(\sigma-(1-\gamma) \alpha-(1-\beta) \sigma(1-\alpha))<0$, approaching the result for the model with exogenous markup. However, as $\lim _{n \rightarrow 1}, \frac{\partial v}{\partial \bar{K}}>0$, since $\frac{1}{n-1} \rightarrow \infty$, and there is no solution for $n=1$. Finally, $\frac{\partial v}{\partial \bar{K}}=0$ for $n=1+\frac{B}{(1-\beta)(\sigma-(1-\gamma) \alpha-(1-\beta) \sigma(1-\alpha))} . \quad$ Consequently, $\quad \frac{\partial v}{\partial \bar{K}}>0 \quad$ for $n<1+\frac{B}{(1-\beta)(\sigma-(1-\gamma) \alpha-(1-\beta) \sigma(1-\alpha))} \quad$ and $\quad \frac{\partial v}{\partial \bar{K}}<0 \quad$ for $n>1+\frac{B}{(1-\beta)(\sigma-(1-\gamma) \alpha-(1-\beta) \sigma(1-\alpha))}$.

\section{Proof of Proposition 3}

To determine the direction of trade as specified in Proposition 3, I first undertake to analyze the balance of payments in components $C=n^{h} p^{*} x^{*}-(1-\gamma) \alpha I^{h}$. Noticing that $n^{h} p^{*} x^{*}=n^{h} r^{*} \theta \sigma$ and substituting for $n^{h}$ from (43) allows to reach, after some manipulation, $C=n^{h} p^{*} x^{*}-(1-\gamma) \alpha I^{h}=(1-\alpha) \sigma(1-\beta) \frac{w^{*}}{r^{*}} \bar{L}^{f}+(1-\gamma) \alpha \frac{w^{*}}{r^{*}} \frac{L}{K}^{*} \bar{K}^{h}-(1-\alpha) \sigma(1-\beta)$. $\cdot \frac{w^{*}}{r^{*}} \frac{\bar{L}^{*}}{\bar{K}^{*}} \bar{K}^{f}-(1-\gamma) \alpha \frac{w^{*}}{r^{*}} \bar{L}^{h}=(1-\alpha) \sigma(1-\beta)\left(\bar{L}^{f} \bar{K}^{h}-\bar{L}^{h} \bar{K}^{f}\right) \frac{w^{*}}{r^{*}} \frac{1}{\bar{K}^{*}}+(1-\gamma) \alpha$. $\cdot\left(\bar{L}^{f} \bar{K}^{h}-\bar{L}^{h} \bar{K}^{f}\right) \frac{w^{*}}{r^{*}} \frac{1}{\bar{K}^{*}}=\left(\bar{L}^{f} \bar{K}^{h}-\bar{L}^{h} \bar{K}^{f}\right)((1-\gamma) \alpha+(1-\alpha) \sigma(1-\beta)) \frac{w^{*}}{r^{*}} \frac{1}{\bar{K}^{*}}$. Here $\bar{K}^{*}=\bar{K}^{h}+\bar{K}^{f}$ and respectively for labor. This expression is positive for $\frac{\bar{L}^{f}}{\bar{K}^{f}}>\frac{\bar{L}^{h}}{\bar{K}^{h}}$ and negative for $\frac{\bar{L}^{f}}{\bar{K}^{f}}<\frac{\bar{L}^{h}}{\bar{K}^{h}}$.

To show what sign $w^{*} L_{m}^{h}-\gamma \alpha I^{h}$ takes, notice from the full employment condition in (6) that $L_{m}{ }^{h}=\bar{L}^{h}-L_{s}-\lambda n^{h} x^{*} \quad$ and $\quad$ that $\quad L_{s}=\beta(1-\alpha) \frac{I^{h}}{w^{*}} . \quad$ After substituting, $w^{*} L_{m}^{h}-\gamma \alpha I^{h}=(1-\alpha)(1-\beta)(\sigma-1) \frac{w^{*}}{r^{*}} \frac{\bar{L}^{*}}{\bar{K}^{*}} \bar{K}^{f}-(1-\alpha)(1-\beta)(\sigma-1) \frac{w^{*}}{r^{*}} \bar{L}^{f}-$ 


$$
\begin{aligned}
& -(1-\beta(1-\alpha)-\gamma \alpha) \cdot \frac{w^{*}}{r^{*}} \frac{\bar{L}^{*}}{\bar{K}^{*}} \bar{K}^{h}+(1-\beta(1-\alpha)-\gamma \alpha) \frac{w^{*} \bar{L}^{h}}{r^{*}}=(1-\alpha)(1-\beta)(\sigma-1) \cdot \\
& \cdot\left(\bar{L}^{h} \bar{K}^{f}-\bar{L}^{f} \bar{K}^{h}\right) \frac{w^{*}}{r^{*}} \frac{1}{\bar{K}^{*}}+(1-\beta(1-\alpha)-\gamma \alpha)\left(\bar{L}^{h} \bar{K}^{f}-\bar{L}^{f} \bar{K}^{h}\right) \frac{w^{*}}{r^{*}} \frac{1}{\bar{K}^{*}}=\left(\bar{L}^{h} \bar{K}^{f}-\bar{L}^{f} \bar{K}^{h}\right) \cdot \\
& \cdot(1-\beta(1-\alpha)-\gamma \alpha+(1-\alpha)(1-\beta)(\sigma-1)) \frac{w^{*}}{r^{*}} \frac{1}{\bar{K}^{*}}=\left(\bar{L}^{h} \bar{K}^{f}-\bar{L}^{f} \bar{K}^{h}\right) \cdot \\
& \cdot((1-\gamma) \alpha+(1-\alpha) \sigma(1-\beta)) \frac{w^{*}}{r^{*}} \frac{1}{\bar{K}^{*}} . \text { This expression is positive for } \frac{\bar{L}^{f}}{\bar{K}^{f}}<\frac{\bar{L}^{h}}{\bar{K}^{h}} \text { and negative for } \\
& \frac{\bar{L}^{f}}{\bar{K}^{f}}>\frac{\bar{L}^{h}}{\bar{K}^{h}} \cdot
\end{aligned}
$$

\section{Proof of Lemma 1}

To prove Lemma 1, I make use of the expressions for the world intermediate good output $I_{m}^{*}=x^{*}\left(n^{h\left(\frac{1}{\rho} \frac{\sigma}{\sigma-1}\right)}+n^{\left.f\left(\frac{1}{\rho} \frac{\sigma}{\sigma-1}\right)\right)^{\frac{\sigma}{\sigma-1}}}\right.$ and the world composite price index $P_{I}^{*}=p^{*}\left(n^{h\left(\frac{\sigma-1}{\rho}-\sigma+1\right)}+n^{f\left(\frac{\sigma-1}{\rho}-\sigma+1\right)}\right)^{\frac{1}{1-\sigma}}$. Notice that analogous to (12), at the world level $P_{I}^{*} I_{m}^{*}=\left(n^{h}+n^{f}\right) p^{*} x^{*}$, since components from both countries are available as inputs. But then $P_{I}^{*} I_{m}^{*}=p^{*} x^{*}\left(n^{h\left(\frac{1}{\rho} \frac{\sigma}{\sigma-1}\right)}+n^{f\left(\frac{1}{\rho} \frac{\sigma}{\sigma-1}\right)}\right)^{\frac{\sigma}{\sigma-1}} \cdot\left(n^{h\left(\frac{\sigma-1}{\rho}-\sigma+1\right)}+n^{f\left(\frac{\sigma-1}{\rho}-\sigma+1\right)}\right)^{\frac{1}{1-\sigma}}=\left(n^{h}+n^{f}\right) p^{*} x^{*}$.

Rewrite this expression to reach $n^{\left(\frac{\sigma-1}{\rho}-\sigma+1\right)}+n^{f\left(\frac{\sigma-1}{\rho}-\sigma+1\right)}=\left(n^{h}+n^{f}\right)^{1-\sigma}\left(n^{h\left(\frac{1}{\rho} \frac{\sigma}{\sigma-1}\right)}+n^{f\left(\frac{1}{\rho} \frac{\sigma}{\sigma-1}\right)}\right)^{\sigma}$. These two sides are equal if and only if $\rho=\frac{\sigma-1}{\sigma}$. 


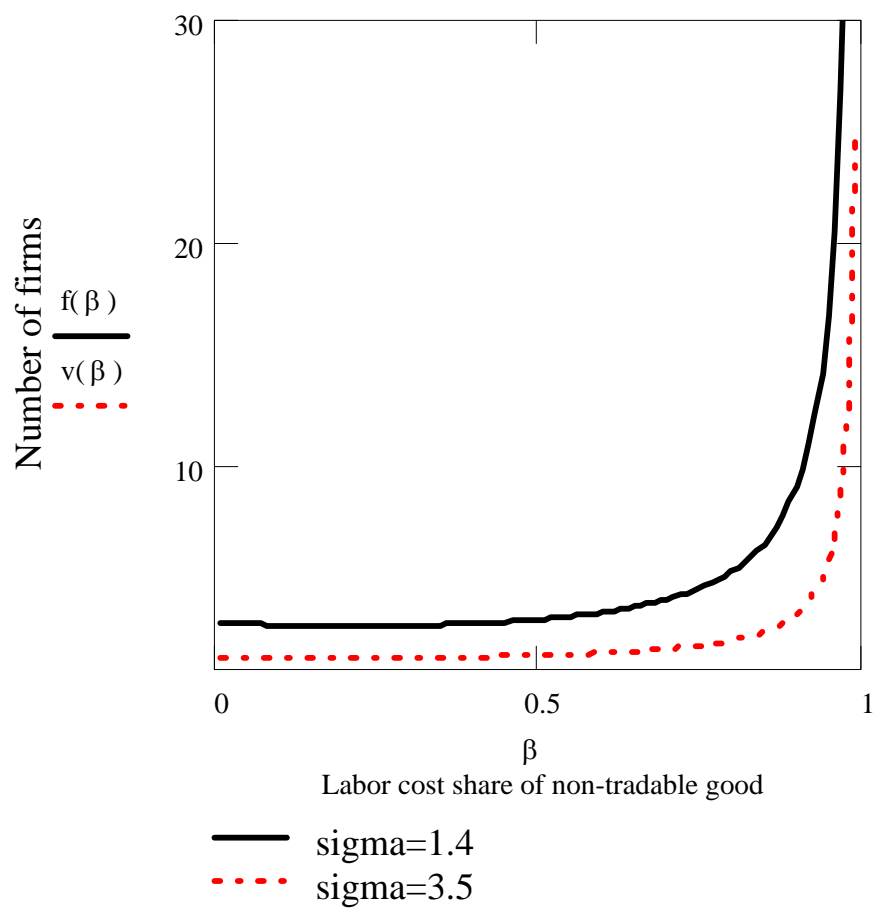

\section{Figure 1. Determination of the threshold level of the number of firms}

The parameter values on the above figure are as follows: $B=0.72, \alpha=0.57$ and $\gamma=0.2$. The labor share of total income $(B)$ is taken as a historic average of the U.S. labor share (total compensation) of national income. The share of tradable goods in consumption $(\alpha)$ is calculated as an average for Canada, Italy, the U.K. and the U.S. from 1970 and 2002 data based on the OECD Annual National Accounts. The share of assembly cost $(\gamma)$ in total costs is taken as an approximate average, as the electronics industry reports assembly costs in the range of $10 \%$ (Advanced Manufacturing Project, 2002) and motor vehicle industry in the range of $30 \%$ (WTO). 
$\left(\Theta_{L}=B=0.72, \Theta_{K}=0.28, \sigma=1.4, \theta=0.52, \alpha=0.57\right.$ and $\left.\gamma=0.2\right)$

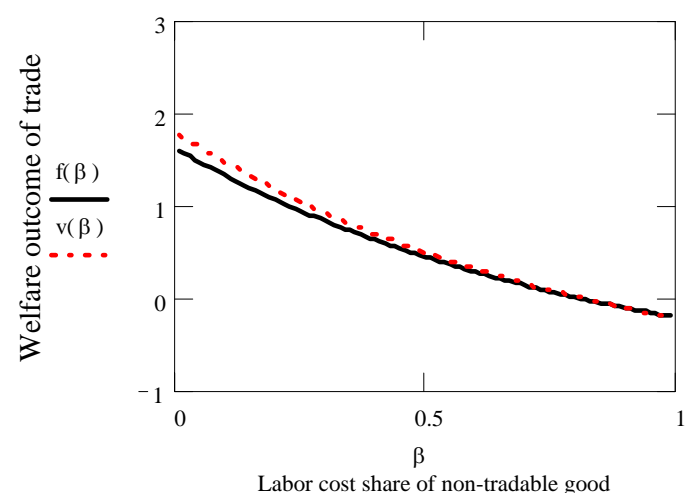

cost share of non-tradable good

$\begin{array}{ll}\text { - exogenous markup } \\ \ldots & \text { endogenous markup }\end{array}$

$$
\frac{\bar{K}^{h}}{\bar{L}^{h}}=0.15, \frac{\bar{K}^{f}}{\bar{L}^{f}}=0.83
$$

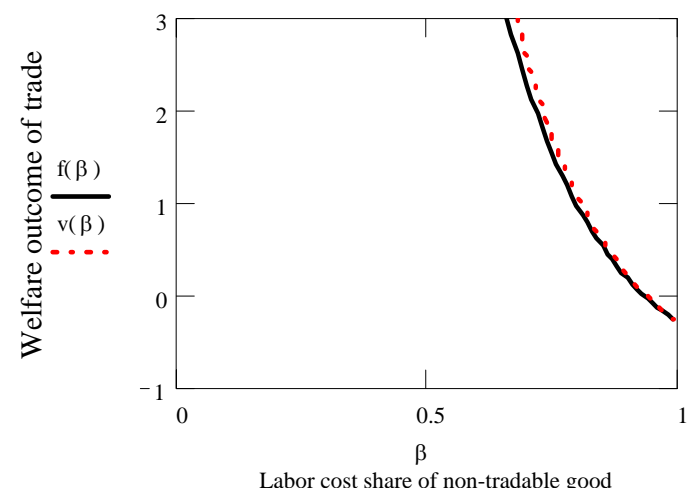

Labor cost share of non-tradable good

exogenous markup ... endogenous markup

$\frac{\bar{K}^{h}}{\bar{L}^{h}}=0.004, \frac{\bar{K}^{f}}{\bar{L}^{f}}=1.236$

\subsection{Capital-abundant home country}

$\left(\Theta_{L}=B=0.72, \Theta_{K}=0.28, \sigma=1.4, \theta=0.52, \alpha=0.57\right.$ and $\left.\gamma=0.2\right)$

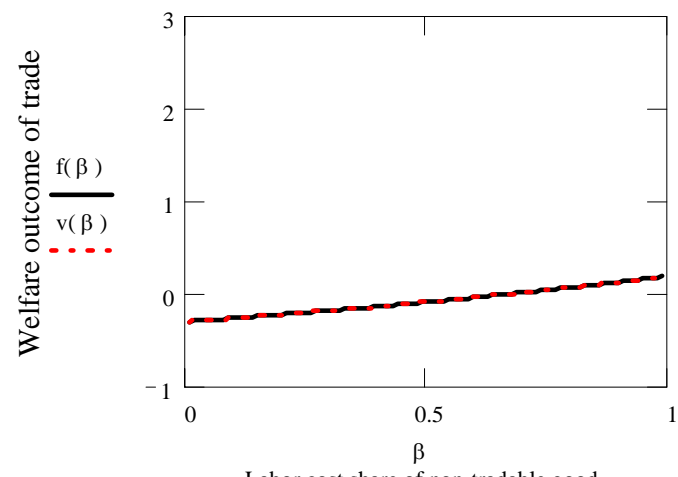

Labor cost share of non-tradable good

- exogenous markup

... endogenous markup

$$
\frac{\bar{K}^{h}}{\bar{L}^{h}}=0.83, \frac{\bar{K}^{f}}{\bar{L}^{f}}=0.15
$$
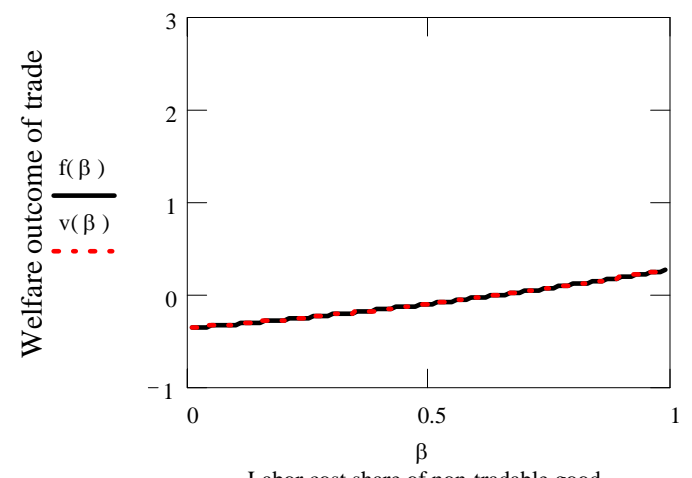

Labor cost share of non-tradable good

— exogenous markup

... endogenous markup

Figure 2. Welfare implications of trade 
Individual researchers, as well as the on-line and printed versions of the CERGE-EI Working Papers (including their dissemination) were supported from the following institutional grants:

- Center of Advanced Political Economy Research [Centrum pro pokročilá politicko-ekonomická studia], No. LC542, (2005-2009),

- Economic Aspects of EU and EMU Entry [Ekonomické aspekty vstupu do Evropské unie a Evropské měnové unie], No. AVOZ70850503, (2005-2010);

- Economic Impact of European Integration on the Czech Republic [Ekonomické dopady evropské integrace na ČR], No. MSM0021620846, (2005-2011);

Specific research support and/or other grants the researchers/publications benefited from are acknowledged at the beginning of the Paper.

(c) Anu Kovaříková Arro, 2005

All rights reserved. No part of this publication may be reproduced, stored in a retrieval system or transmitted in any form or by any means, electronic, mechanical or photocopying, recording, or otherwise without the prior permission of the publisher.

Published by

Charles University in Prague, Center for Economic Research and Graduate Education (CERGE) and

Economics Institute (EI), Academy of Sciences of the Czech Republic

CERGE-El, Politických vězňu 7, 11121 Prague 1, tel.: +420 224005 153, Czech Republic.

Printed by CERGE-EI, Prague

Subscription: CERGE-El homepage: http://www.cerge-ei.cz

Editors: Directors of CERGE and EI

Managing editors: Deputy Directors for Research of CERGE and EI

ISSN 1211-3298

ISBN 80-7343-057-6 (Univerzita Karlova v Praze, CERGE)

ISBN 80-7344-046-6 (Národohospodářský ústav AV ČR, Praha) 
CERGE-EI

P.O.BOX 882

Politických vězňů 7

11121 Praha 1

Czech Republic http://www.cerge-ei.cz 